Portland State University

PDXScholar

7-30-1976

\title{
William Dunbar: An Analysis of His Poetic Development
}

G. David Beebe

Portland State University

Follow this and additional works at: https://pdxscholar.library.pdx.edu/open_access_etds

Part of the English Language and Literature Commons, and the Rhetoric and Composition Commons Let us know how access to this document benefits you.

Recommended Citation

Beebe, G. David, "William Dunbar: An Analysis of His Poetic Development" (1976). Dissertations and Theses. Paper 2385.

https://doi.org/10.15760/etd.2382

This Thesis is brought to you for free and open access. It has been accepted for inclusion in Dissertations and Theses by an authorized administrator of PDXScholar. Please contact us if we can make this document more accessible: pdxscholar@pdx.edu. 
AN ABSTRACT OF THE THESIS OF G. David Beebe for the Master of Arts in English presented July 30, 1976.

Title: William Dunbar: An Analysis of His Poetic Development. APPROVED BY THE MEMBERS OF THE THESIS COMMITTEE:

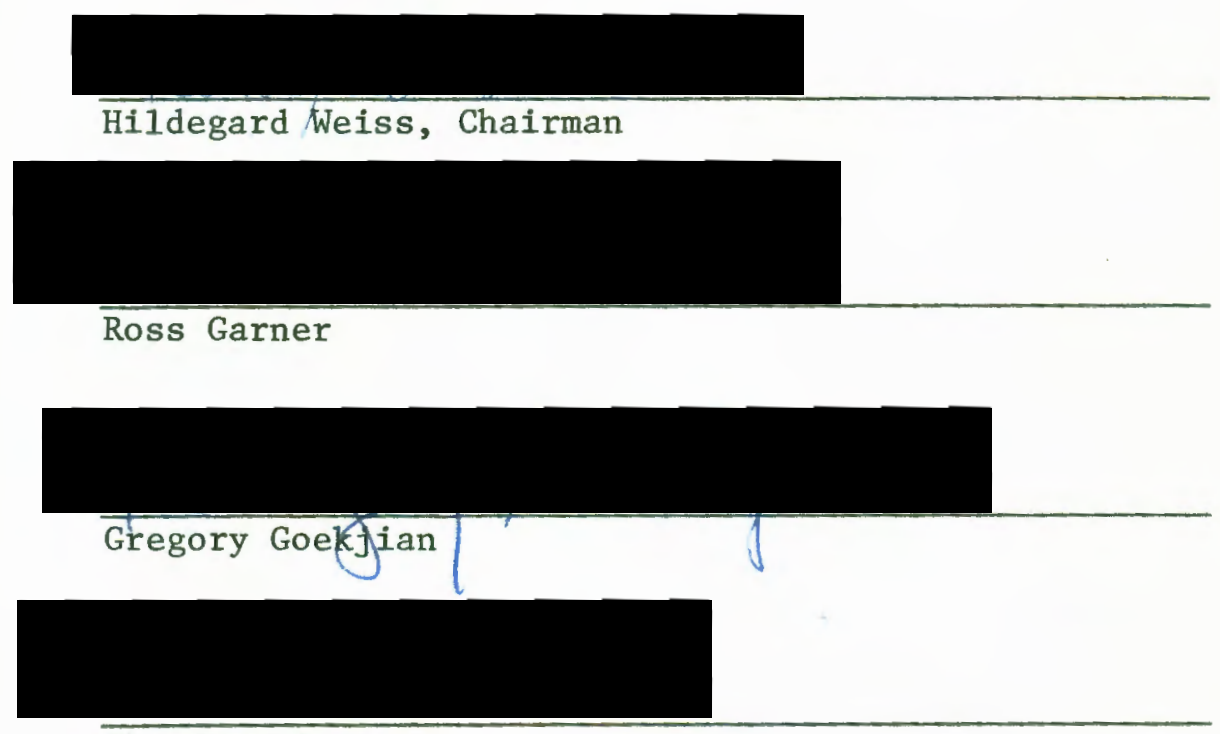

Theodore Grams

This thesis examines the work of William Dunbar, a sixteenth century Scottish poet, in order to demonstrate that he is not, as he is often styled, a Scottish Chaucerian. It makes an analysis of the chronological occurrence of forms and themes in his poetry which indicates that his work can be divided into three periods: (1) an initial period in which his work deals with traditional matter and forms; (2) a second period in which he develops a distinctly personal. poetic voice; and (3) a final period in which he perfects this personal 
voice and then relinquishes it for a public, religious one. In turn these three periods indicate Dunbar's poetic growth away from the Chaucerian influence and a concomitant development of his own personal Iyric voice.

It concludes by examining areas in which Dunbar and Chaucer deal with similar material, revealing that even in areas of similarity, Dunbar's voice is uniquely his own. His distinct poetic voice is then emphasized through an explication of "The Petition of the Gray Horse, Auld Dumbar" which not only prefigures Renaissance poetry but as well exhibits those qualities in his poetry which make his an outstanding Scottish "makar." 
WILLIAM DUNBAR: AN ANAIYSIS OF

HIS POETIC DEVELOPMENT

by

G. DAVID BEEBE

A thesis submitted in partial fulfillment of the requirements for the degree of

\author{
MASTER OF ARTS \\ in \\ ENGLISH
}

Portland State University

1976 
TO THE OFEICE OF GRADUATE STUDIES AND RESEARCH:

The members of the Committee approve the thesis of

G. David Beebe presented May 21, 1976.

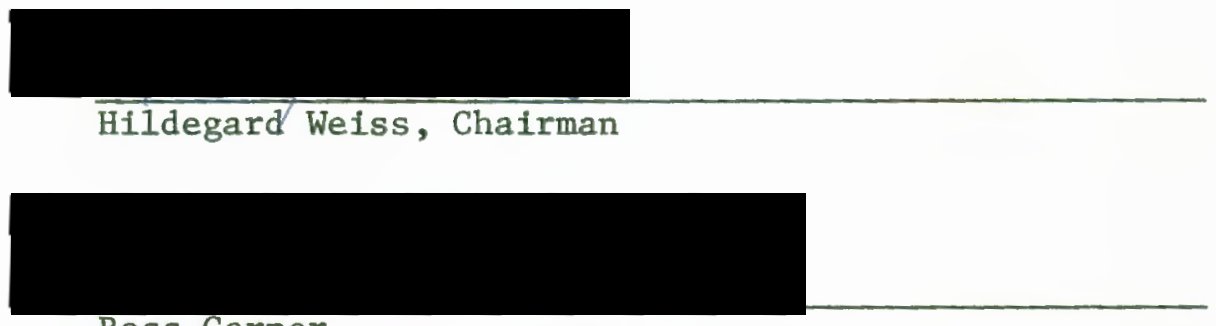

Ross Garner

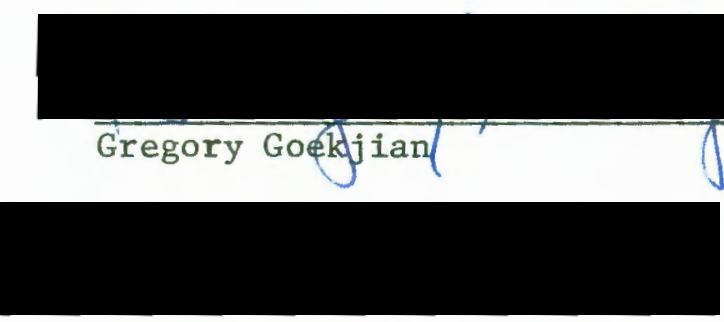

Theodore Grams

APPROVED :

Frederick Waller, Head, Department of English

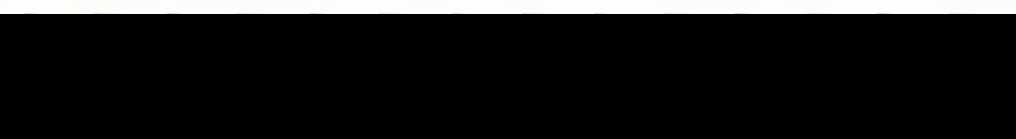

Richard B. Halley, Acting Dean of Graduat d Studies and Research $\int$ 
TABLE OF CONTENTS

PAGE

CHAPTER

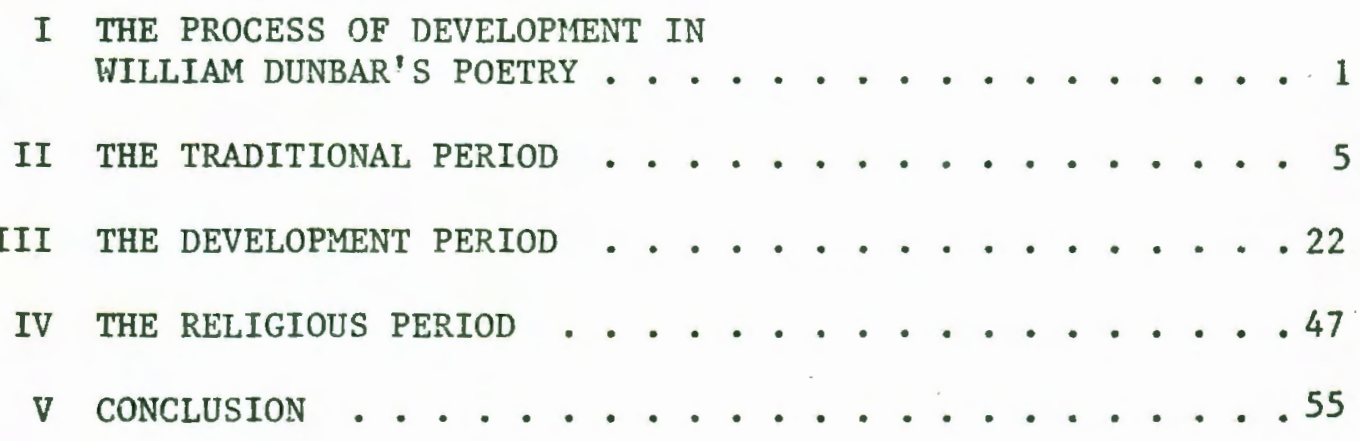

BIBLIOGRAPHY ... . . . . . . . . . . . . 69

APPENDIX A

CHRONOLOGICAL CHART OF THERES AND FORMS ......... 71

APPENDIX B

SELECTED POEMS ................. . . 74 


\section{CHAPTER I}

William Dunbar (1460-1520?), a Scottish poet or "makar" in the court of King James IV, is known as a Scots-Chaucerian, a title which, while it may adequately describe a small portion of his work, denies the integrity and originality of the majority of it. This thesis is intended to demonstrate that originality and integrity through an anaIysis of the chronological occurrence in Dunbar's poetry of particular themes, styles, and stanzaic patterns.

Dunbar's poetic career may be divided into three periods: the traditional, the developmental, and the religious. During the first of these, the traditional period, he experiments with a number of established forms and structures and employs two widely divergent levels of diction: the highly aureate, polysyllabic language of such allegories as "The Goldyn Targe" (非12) and "The Thistle and the Rose" (价4) and the homely colloquial style of his satiric works, of which "The Tua Marift Wemen and the Wedo" (非) is the most striking example. In each of these kinds of narrative verse Dunbar invites comparison with Chaucer, but the similarities are more superficial than real. In "The Goldyn Targa," for instance, he takes over the allegorical apparatus and the technique of introaucing his poem that he found in the dream visions of Chaucer and of Chaucer's French antecedents, but Dunbar's technical virtuosity in this poem is his own. In his satiric works, too, Dunbar achieves effects rather different from those of the fabliaux of Chaucer, with which Dunbar's comic works have frequently been 
compared. The range and focus of Dunbar's satiric voice is different from Chaucer's, extending in a number of the poems to bawdy and burlesque effects closer in tone to the irreverent works of the Goliards. In the remaining types of verse of his first period -- in the vituperative poems and the moral and laudatory verse -- Dunbar speaks with a public voice, with the voice in effect of a poet laureate, and thus in highly conventional forms and tonalities. But even here the qualities of his technical achievement individualize his verse although. he does not attempt to speak in the distinctively personal vol.ce that gives intensity to his later vituperative verse and depth of feeling to the moral and reflective poems of his later perfods.

In Dunbar's second chronological period he continues and extends his experimentation with forms and themes, producing a variety of courtIy lyrics, including occasional and laudatory verse, hymns of praise, and a number of moral and reflective works, as well as a body of vigorously humorous and satiric poems. Although many of these are conventional in structure, the group as a whole reflects an increasingly individual style, farticulariy in the introspective poens and in the long vituperative harangues which frequently preface such precatory poems to the King as "Dunbar's Complaint" (非7) and "Lunbar's Rzmonstrance" (非8). The only examples of Dunbar's speaking with a public or impersonal volice in this period are his Iaudatory poens and the satire "Lady Solfstaris at Court" (非0). In the remainder of the poems his voice becomes increasingly personal. And as his use of the personal voice increases, the number of themes and forms occurring in his work decreases.

In his third and final period, Dunbar devotes his energies almost entirely to moral and religious verse. The satiric and at times quer- 
ulous tone of the poems of his earlier periods now yields on the one hand to the very personal reflective tone of such lyric achievements as "Meditatioun in Wyntir" (非75) and "Of the Changes of Lyfe" (非76) and on the other hand to the formal ceremonial tone of his many hymns. This thesis had its inception in a short critical paper which I wrote on "The Lament for the Makaris." In writing that paper I discovered that Dunbar has received little critical attention. With the exception of biographical studies, few critics have written on Dunbar during this century, and of those few only one or two have given detailed attention to more than three of his poems. I began to read the body of Dunbar's work to discover whether my own evaluation of the poetic quality of "The Lament" was supported by his other poems. In reading selections from several short collections of his work I became aware of the wide range of forms and themes he experiments with; I also discovered how varied are the opinions of the editors as to how the themes and forms should be categorized. I began to keep a notebook in which I analysed the form and subject of each poem as I found 1t. Eventually I obtained the Scottish Text Society's The Poems of William Dunbar, which not only confirms my own analysis of his stanzaic forms but suggests the most sensitive classification of his themes. In addition, the STS edition contains a chronology of Dunbar's poetry. While examining this chronology I discovered, by placing my stanzaic analysis in the suggested chronological order, that the forms which Dunbar uses begin gradually to diminish in number at a mid-point in his poetic career. This fact suggested a possible pattern of development in his poetry. With the purpose of establishing this pattern, I classed each poem according to its theme and again arranged the poems in 
chronological order. By this procedure I found that Dunbar's poetry falls into thematic groups or clusters written at about the same time and that as the number of themes declines, the number of forms does also. To verify this pattern of development, I made a stylistic ana1ysis of each poem. This analysis brought me to the conclusion that Dunbar's foetry represents three periods of development with each perlod marking a distinct kind of achievement. I found in the second period, particularly in the strong personal voice of this period, the finest of Dunbar's poetry. This period also offers the widest range of forms and themes. But I found too that the three periods are united by characteristics which distinguish Dunbar's poetic voice from any other -- such characteristics as the "bon mot"; an extraordinary sty1istic range and flexibility; and arresting resonance of tone; metric preciston; and, finally, a deft handling of the device of reversal, whether managed by means of a slight verbal shift, as in "the 111y of pleasure" of "To a Ladye" or by means of juxtaposing two widely different levels of diction, as in "The Tua Mariit Wemen and the Wedo."

This thesis defends that conclusion through an analysis of the forms, themes, and styles of particular poems, an analysis which not only verifies that conclusion, but which demonstrates the specific aspects of Dunbar's development.

In a11 cases this analysis relies upon the STS edition of Dunbar's poetry as the definitive text. As well, it relies upon A.J.G. Mackay's chronology in the STS edition as the definitive chronology. 
CHAPTER II

The first phase of Dunbar's poetic development includes the poems numbered from one to sixteen. In general the poems of this period are less characteristic of the poet than the poems of his later periods. In some types of verse the tone is gentler, less incisive, than the tone of later poems of the same type. In addition, Dunbar speaks with a less personal voice in these early poems, rarely hazarding overt expression of his opinions or judgements. The fact that Dunbar is much more confidently personal in later poems is not to say, however, that he is no more than an apprentice in this period. As C.S. Lewis notes in English Literature in the Sixteenth Century, "when he first comes before us he is already fully armed and master of his weapon." 1 But if it is true that he is master of his craft, he has not yet achieved his full mastery, as a chronological view of the poetry will show. Much experimentation and refirement of technique are to come before he writes with the confidence and strength that are characteristic of his best poetry.

In Dunbar's first period he writes seven of the ten types of verse he writes in the whole of his career. (See Appendix 1.) He writes the only ailegories and narrative verse of his career and, with the exception of three later poems, produces all of his humorous verse as well. Among the types of poems are precatory, vituperative, moral, and laudatory poems. In respect to metrical and stanzaic forms, at this time he writes in twelve of the sixteen forms he employs in the 
whole of his career. This group includes the only instance of formal1y alliterative verse, in the narrative "Ihe Tua Marilt Wemen and the Wedo" (非); the only occurrence of triolets, in the humorous "The Dregy" ("\#4); and the only stanza of nine equal lines without refrain, in the allegory "The Go1dyn Targe" (代12).

Only one of the poems in this group is precatory, "A New Years Gift to the King" (非). In refrained quatrains, this poem is a relatively gentle handling of a theme that dominates much of his later poetry. Dunbar devotes four stanzas to wishing the King such biessings as joy, gladness, comfort, solace, virtue, grace, fair fortune, felic1ty, peace, and justice. In the fifth and final stanza he wishes the King many French crowns and makes reference to the King's liberal heart, thus shifting the emphasis of the poem from well wishing to petition. The shift is a characteristic example of Dunbar's technique of reversal. But here the general tone of the poem is pleasant; the language ts the speech of everyday, plain but light. In the precatory poems of Dunbar's later periods, the irony is more forceful and the general tone harsher, more aggressively critical and petitionary. Seven of the sixteen poems, nearly half of this period's work, are humorous pieces. The first of these, "The Tod and the Lamb" (\#2), is written in septets made up of three iambic tetrameter couplets and a refrain line. It treats satirically the activities of some of the courtiers and nost probably the King himself but under the guise of a beast fable concerned with seduction. The poen tells of a fox's attempt to seduce a lamb and of his being interrupted by a wolf whose territory the fox seems to have invaded. The fox escapes by disguising himself in sheep's ciothing. The satiric point of the poem emerges 
only in the last line, in which the refrain of the previous nine stanzas, "And that me thocht ane ferly cace", is altered to "How at Dumfermling fell the cace." Thus in a single final line Dunbar converts a familiar moral fable into a pointed barb directed to a particular incident in the court. The language of the poem is appropriately low colloquial.

The language of the second poem of the group, "Ane Brash of Wowing" (\#3), is even lower, as one stanza should suffice to indicate:
Quod he, "My claver, and my curldodie, My huny scppis, my sweit possodie. Be not oure bosteous to your billie Be warme hairtit and not ewill willie; Your heylis, quhyt as quhalis bane, Garris ryis on loft my quhillelillie; Ye brek my hart, my bony ane!"

The theme is again seduction but the humor lies in Dunbar's extremely burlesque treatment of a troubadour form, the pastourelle, which is usually distinguished by the wit and delicacy with which it is handled. The parodic quality of the language is the primary humorous device, but the shift in the refrain of the final two stanzas is also used for ironic effect.

Just as these two poems are companion pieces on seduction, so "The Twa Cumeris" (非7) and "The Ballad of Kynd Kitok" (非) are two of a kind, dealing humorously with the vice of drinking. "The Twa Cummeris" tells of two women sitting by the fire on Ash Wednesday morning, drinking and complaining that the long Lenten fast has made them thin. Similarly, "The Ballad of Kynd Kitok" tells of one woman's love of drink being so great that, having died of thirst and made a good end, she found the "Aill of hevin wes sour" and so slipped out "of hevin the hie gait" to get a better quality of ale. Both poems are written 
in lively colloquial language; the first is written in the refrained cinquain, the second in the wheel.

of Dunbar's humorous verse in this first pariod one poem stands out as unusual. "The iregy," ("4) subtitied "maid to the Kyng, bydand our lang is Striuiling," is a parody in octesyllabic couplets, of the Mass for the Dosd, the "dregy," or dirge, occasicned by the King's lodging with the Franciscans at Stirling. The language level and the poetic devices Dunbar uses are similar to those which characterize much of his later work. He prays that James may be delivered from his penance in the "pergatory" of Stirling to the "paradys" of Edinburgh before the Yule season begins. Included in "The Dregy" is a Latin parody of a portion of the "Our Father:"

Et ne nos inducas intemptationem de Strivilling:

Sed libera nos a malo illius.

Requiem Edinburghi dona eiis, Domine, Et lux ipsius luceat eiis.

We do not know how the Franciscans received this poem in Stirling, but It is apparent that Dunbar hopes with his humor to cajole James into returning to Edinburgh castle. Dunbar's parody here has a double edge. On the one hand, he presents the court and himself as a choir of angels; on the other, he depicts James as a penitent in purgatory where he "eitis nocht meit restorative,/Nor drynkis" no wyn confortative, /Nor a111 bot that is thyn and smail" (1. 11-13). Dunbar's mock high seriousness of tone, one supposes, is meant both to caricature the King's surroundings and to entice him to better.

The last of the humorous pieces in this period are the two long narrative poems, "The Tua Mariit Wemen and the Wedo" (非6) and "The Freirls of Berwik" (\$8). The chief distinction of the first of the 
two is that Dunbar's earthy women are more obscenely revealing in their dialogue than is Chaucer's Wife of Bath. The poem is also characteristically ironic in that the grossness of the women's conversation is absurdly at odds with the idealized setting that Dunbar provides for it. Unlike any other poem in the Dunbar canon, it is in alliterative verse, perhaps the cldest poetic form that Dunbar uses. The second of the long narrative poems is a fabliau in written decasyllabic couplets. The tale concerns the infidelity of an innkeeper's wife with a black friar, the discovery of their affair by two white friars, and the way the friars use their knowledge to gain an evening's entertainment. The poem is reminiscent of Chaucer's fabIlaux, his "Miller's Tale" and "Reeve's Tale," though Dunbar is perhaps not as dramatically lively nor as subtle in his irony as is Chaucer. Most prominent of the poetic devices occurring here is alliteration, head rhyme in particular, coupled with the cataloguing which is frequently found in Dunbar:

The toune, the wall, the cas tell and the land, The he wallis upon the upper hand The grit croce kirk, and eik the Masone Dew, The Jacobene freiris of the quhyt hew, The Carmeleitis, and the monkis eik; The four ordoris wer nocht for to seik, Thay wer all in this toun dwelling.

The cataloguing effect coupled with the ordered repetition of sounds and phrases collides with the disorder of events to contribute to the satiric effect of the whole. The poem is the last of Dunbar's Iong narrative works, this fact suggesting that his interests and talents lay in other directions.

The next category to be considered is Dunbar's vituperative verse, a type of poetry that becomes most prominent in his middle period. In 
the first period, however, he has only one poem in which his purpose is verbal castigation of those he looks upon as opponents. The poen, "Aganis the Solistaris in Court" (佔5), has the poetic devices characteristic of his later vituperatives, but it is less caustic. It is not that the devices are less effective here, but rather that they are used differently. Consider the following passage:

Be divers wyis and operatiounes

Men makis in court thair solistationes:

Sum be service and diligence, Sum be continuall residence;

Sum one his substance dois abyd, 1.5 Quhillfortoune do for him provyd; Sum singis, sum dances, sum tellis storyis, Sum lait at evin bringis in the moryis; Sum flirdis, sum fenyeis, and sum flatteris, Sum playis the fule and all owt clatteris; 1.10 Sum man, musand be the waw, Luikis as he mycht nocht do with aw; Sum standis in a nuk and rownes, For covetyce ane uthair neir swownes;

Sum beris as he wald ga wud

For hait desyr off warldis gud;

Sum at the mes leves all dovecion, And besy labouris for premocione; Sum hes thair advocattis in chalmer, And takis thame selff thair no glawmir

My sempillnes amang the laiff Wait off na way sa God me saiff! Bot, with ane humil cheir and face, referris me to the Kyngis grace: Me think his graciows countenance In ryches is my sufficiance.

Although the tone is self-effacing, Dunbar is speaking as a courtier seeking the favor of the King by displaying the unworthiness of his fellows. Dunbar achieves this effect through a careful correlation of his theme and structure. Notice that the poen is divided into two sections. The first section is an extended catalogue of the other members of the court and their vices. The second stanza is fairly short. It states that Dunbar does not seek money from the King, that the King's 
"graciows countenance" is sufficient for him. The implication here is that because Dunbar does not seek the King's gold he should receive it, the King having recognized Dunbar's worth. Supporting this thematic development is the construction of the poem itself. Besides the stanzaic separation of Dunbar from the rest of the court, there is the frequent use of parallel lines in the first section to create an effect of auditory and visual unification within the stanza and thus to emphasize the separation. Dunbar lumps his fellow courtiers into an indefinate, indolent mass through the repeated use of the impersonal word "sum." He further emphasizes his distaste for this group by changes in meter. Thus he shows less antipathy for those who make their solicitations "be service and diligence" than he does for that group of courtiers in which "Sum singis, sum dances, sum tellis storyis." His cursory listing of the latter group demonstrates that group's lack of importance in the court. The change in rhythm is seen more sharply if the line is compared with the leisurely opening of the second stanza: "My sempillnes amang the laiff/Wait off na way, sa God me saiff!" Similarly. the poem as a whole is softened by the slower, multi-syllabic lines that open and close it. The words "operatiounes," "solistationes," "countenance," and "sufficiance," create a slower entry and exit from the poem by contrast with the quick, abrupt words that make up the middle.

"Aganis the Solistaris" sets the general pattern for Dunbar's other vituperative poems. Typically Dunbar's poems in this vein include a catalogue of the courtly fops and solicitors, as well as the rhythmic changes and parallel structures that were noted in this poem. They also include a device similar to the device of parallel lines and probably growing from it, which I have chosen to call "head rhyme" for 
lack of a technical name. Head rhyme is the repetition of the initial word of one line in subsequent, although not necessarily consecutive 1ines. The repetition must be more than incidental to be considered head rhyme. The effect of this poetic device has already been seen in "Aganis the Solistaris." It creates a visual, auditory, and tonal pattern that unifies several lines, stanzas, or an entire poen in much the same way that alliteration does. In comparison with later vituperative works, however, "Aganis the Solistaris" is not highly alliterated; the poem merely hints at the ailiterative bite of the later poems. In the fourth category of verse, the moral poem, we have only one work in this period: "Learning vain without guid Lyfe" (\#10). The poem is thought to have been written at Oxford during Dunbar's service with the ambassadors sent by James to the English court. ${ }^{4}$ In the three stanzas of the poem Dunbar gives instruction to the "elarkis" of Oxford: "be myrrouris in your governance/And in our darkness be lampis in schyning." The point of this suggestion is his refrain line that "A paralus seikness is vane prosperite." The poem begins with a conventional catalogue.

$$
\begin{aligned}
& \text { To speik of science, craft, of sapience, } \\
& \text { off vertew mora11, cunnyng, or doctrene, } \\
& \text { off jure, of wisdome, or intelligence, } \\
& \text { off everie study, lair, or disciplene; } \\
& \text { All is bot tynt or reddie for to tyne, }
\end{aligned}
$$

Notice that each of the first four lines is made up of units of three. Each set of units is begun with the word "of," which is followed by two units, the word "or" and the final unit. This repetition of pattern holds the 1ist together. Dunbar varies his structure in the third Iine by introducing the first and second unit with the word "of." His fifth line divides into two parts connected by the word "or," giving 
the catalogue a finish which ties into the pattern by the use of one of the key words. Similarly, his second stanza begins with four parallel lines, in this case two lines parallel to the subsequent two.

The curious probatioun logicall, The eloquence of ornat rethorie, The naturall science philosophicall,

The dirk appearance of astonomis,

Despite the poem's technical features, however, it lacks the vitality of many of Dunbar's later moral poems. It smacks of the more conventional of his occasional or laudatory poems, the type of verse to be considered next in this period.

Functioning in effect as poet laureate of the Scottish court, Dunbar writes scattered laudatory verse throughout his career. In such verse he rarely matches the achievement of the period in which it 1s written, for his handling of praise tends to be conventional, with no evident change from period to period. Of the two laudatory poems of this perfod, "In Praise of London," (非1) and "Welcome of Margaret as Queen of Scotland" (非15), the latter provides an excellent example of the convention while also demunstrating Dunbar's use of highly alliterative style.

\footnotetext{
Now fayre, fayrest of $\bar{f}$ every fayre, Princes most plesant and preclare, The lustyest one alyve that byne, Welcome of Scotland to be Quene!
}

Younge tender plant of pulcritud, 1.5 Descendyd of Imperyalle blude;

Fresche fragrant floure of fayrehede shene, Welcum of Scotland to be Quene!

Typically Dunbar uses this highly alliterative style when he is trying to be vehement, as in his laudatory and vituperative poems and in a few of his religious works. He uses alliteration judiclously and with 
great skill in much of his poetry, evoking'a strong emotional effect by a correspondingly heavy use of alliteration as here, in "Welcome of Margaret," for instance.

One type of verse, allegory, remains to be considered in the first segment of Dunbar's poetic career. His allegories represent one of the traditional aspects of his work in this period. Two of his allegories in particular are within the courtly tradition of Guillaume de Lorris and Chaucer. Both "The Goldyn Targe" (非12) and "Beauty and the Prisoner" (非13) follow this tradition closely. Indeed, "The Goldyn Targe" cites Chaucer as the "rose of rethoris all" (1.254) in one of its final stanzas. In this poem the poet tells how he falls to dreaming on a May morning. While asleep he witnesses the gathering of "ane hundreth ladyes" (1.58) on one hand and a court ruled by cupid on the other. he is seen by the ladies as subsequently attacked by the various aspects of love such as "Beautee," "Fair Having," "Plesance" and "Chere." Reason comes to his rescue and protects him with his golden shield, but the poet is captured and delivered to "Hevyness." The apparitions then take to their ship and fire their cannon. The poet awakens, stating that Chaucer "This mater could illumynit have full brycht" (1.258) and cormends his p.oem with a humble envoi. of particular interest in the poem is Dunbar's description of natural surroundings, which, significantly, he presents in vivid detail in only one other poem, "The Thistle and The Rose." One example from "The Goldyn Targe" should suffice to demonstrate the clarity with which he presents the setting of his poem:

Doun throu the ryce a ryuir ran wyth stremys, So lustily agayn thai lykand lemys, That all the lak as lamp did leme of licht, 
Quhilk schadovit all about wyth twynkling glemis;

That bewis bathit was in secund bemys

Throu the reflex of Phebus visage brycht;

On every syde the hegies raise on hicht,

The bank was grene, the bruke vas full of bremys,

The stanneris clere as stern in frosty nycht.

The poem has received considerable critical attention in recent years, the most provocative study being perhaps that of Denton Fox, who not only praises the poem highly but discovers in it a level of meaning missed by earlier critics. His view, that the poem is on one level a treatise on the art of poetry, is supported and expanded by Lois Ebin ${ }^{6}$ in a subsequent article. The convincing argument the two critics make suggests that the poem is another example of Dunbar's adapting a conventional form to his own purpose, in this case the use of the traditional courtly love dream vision to put forth his own ideas about the relationship between the poet and his craft.

"The Thistle and the Rose" resembles "The Goldyn Targe" in that it is a courtly love allegory employing some of the same allegorical figures - such figures as.Flora, Aurora, Natur, Eolus, Neptunus, Juno, May, and Venus. "The Thistle and the Rose" depicts the marriage of James and Margaret, one of the most important occasions of Dunbar's career. In allegorical terms he tells how he wakes one morning to find "fresche May" standing before his bed. She admonishes him to get out of bed and begin to write: he had promised her to "discryve the Ross of most plesance" (1.39). He rises and follows her to a garden where he sees the figures previously mentioned. Dame Nature has called all of her beasts and flowers to attend her there. She is first approached by the lion, "greatest of degre." (By his description Dunbar makes the association of the lion with the the King and kingdom. 
He describes the lion as "Reid of his collour, as in the ruby glance, / On felld of gold he stude full mychtely, With flour delycis sirculit lustely" (1.96-98). This is a description of James' Coat-of-arms.) Nature crowns the 1ion, and all of the beasts shout "Viue le Roy" at the sight. In a similar manner although in a briefer passage, the eagle is also crowned. "The Awfull Thrissill" next draws near, and is crowned with "a radius croun of rubeis" (1.132) and admonished to take particular care of the "Ross." Dame Nature then addresses and crowns the Rose. Both beasts and flcwers respond with a several stanza shout for joy.

Similar to "The Goldyn Targe" but on a different level is "Beauty and the Prisoner." This poem begins in medias res, in the middle of the action, that is to say, of the traditional courtly love allegory. Skipping past the poet sleeping on a May morning, the discovery of the garden and the sighting of the beloved, elements common to both Chaucer's Romaunt of the Rose and Dunbar's. "The Goldyn Targe," in this poem the poet presents the lover as already in love with "hir that farest is" (1.2), and by her command Beauty takes him to the "castell of pennance" where "Strangenes" guards the door and "Comparesone" keeps the dungeon. "Gud Howp" suggests that the lover write a letter to be borne by "Lawliness" and "Fair Scherwice," "Lawliness" and "Petie" then decide to free the lover by attacking the castle. A battle ensues with "Thocht" in the forefront and "I ust" carrying the banner. The prisoner is rescued and the castle's inhabitants are either slain, as is "Strangenes," or they are put to flight, as "Sklander" who is chased "to the west se cost" by "Matremony." With that the lovers are joined by "the band of friendship," and "Gud Eamiss" is welcomed as a 
member of the court. With the exception of the introduction of "Matremony" in the conclusion, this poem and "The Goldyn Targe" are structurally similar to the courtly love allegories of Chaucer and Guillaume de Lorris, and demonstrate the traditional nature of Dunbar's early poetry.

The last of Dunbar's allegories to be considered is "Ane Littil Interlud of the Droichis Part of the Play." In the form of a monologue, the dwarf "Welth" recounts his unusual ancestry. He says of his grandmother:

Yit ane thin written of his I fynd,

In Yrland quhen scho blew behind, At Norway coist scho raisit. the wynd, And frit schippis drownit thair.

The humor of the poem lies both in the rough, low language and in the figure of the dwarf whose ancestors were all giants. He points to this physical disparity when he says, "Now sen I am suche quantetie/Off gyanis cum, as ye may sie" (1.153). Except for its low language, which is reminiscent of "Ane Brash," this poen is unlike any other in Dunbar's early period.

I have only briefly mentioned the forms of the poems in this period, relegating them to a position of importance secondary to the development of themes and poetic devices. I shall now concern myself with the ray in which the stanzaic patterns of the poems support the three period division of Dunbar's work.

As indicated above, Dunbar uses sixteen patterns of stanzaic development. He uses twelve of these forms in his first period (See chart). Of these twelve, three forms occur only once and only in this period. These three forms are alliterative verse, the triolet, and a 
nine-1ined stanza without a.refrain. Significantly two of these three forms occur in poems whose general structures are also unique to this period. Similarly, all of Duntar's allegorical poems occur in this period and among these, only in "The Goldyn Targe" does he use the nine-line unrefrained stanza. (The third unique form, the triolet, he uses in the "responses" in "The Dregy," whose primary form is the short couplet.) The variety of forms in these sixteen poems and the uniqueness of the three forms just cited demonstrates the traditional nature of his early poetry. It is as though he is displaying his mastery and versatility in his craft in much the same way as apprentices of other crafts do. In effect he has created in this first group of poems a "sampler," a demonstration of his ability to use a variety of themes and forms with the hand of a master of his craft, just as an embroidered samplex demonstrates the artist's ability to work with a variety of stiches. Such a "sampler," to continue with this metaphor, is perforce imitative because its purpose is to display its creator's ability to use the basic skills (the received tradition). The "sampler" reveals the options, the many stiches, that the creator knows are available for his use. Thus, the many forms in Dumbar's first period demonstrate his wide range of stanzaic options as well as his ability to use them in conjunction with traditional subjects. Dunbar does not continue to use all of these forms. As mentioned above, he uses three of them only once in his poetic career, whereas other forms from this period, such as the octet with refrain and cinquain with refrain, are to become his most frequently used forms. This "sampler" includes nearly all of Dunbar's main forms. Of the four forms not included in this period, two, the octet and the four foot octet, are unique occur- 
rences, and one, the refrained sextet, occurs in two poems. The fourth form, the cinquain, is used frequently in his later work.

This is not to imply that Dunbar consciously went about creating a "sampler" of his poetic ability. Rather it indicates that in this first period of his career Dunbar has not yet found his poetic niche. As a body his poems are more like a random sampling than a group of poems from a particular period of a poet. It is this randomness that most distinguishes this period from the others.

The metaphor of the embroidered "sampler" may be applied as well to the internal structures of these poems. I have shown, in conjunction with my discussion of Dunbar's thematic development, that many of the poetic devices which were to become characteristic of the body of Dunbar's work as a whole first appear in this period. I have also shown that this first period contains a very wide range of these devices, and that the same device, such as alliteration, occurs with greatly varying degrees of intensity. Similarly the level of language varies greatly from poem to poem, as greatly as the difference between the language of "Ane Brash of Wowing" and that of "The Goldyn Targe." Despite the variety of effects of these early poems, their lack of thematic and stanzaic similarity, there is a certain homogeneity among them. As I have noted previously, several poetic devices are common to the majority of them. Throughout this initial period Dunbar uses the devices of alliteration and head rhyme, to name two, in a manner that is characteristic of the body of his work as a whole. He uses them with a precision that consistently gives his verse a unity which marks even his most traditionai works as his own. Moreover, despite the wide range of language levels that Dunbar uses, in itself a 
mark of his distinct voice, these devices and the characteristic twist at the end of his verse carry over into the other periods of his development where, through a wide range of stibjects and stanzaic forms, they continue to signify the poetic voice that is William Dunbar. 
${ }^{1}$ C. S. Lewis, English Literature in the Sixtcenth Century (Oxford: Oxford University Press, 1954), p. 91.

2 For those who would label Dunbar as a Scot-Chaucerian this poem contains one of the clues to a relationship between Dunbar's poetry and Chaucer's. The first line of the fourth stanza, line 22 , begins with the words "Tehe!' quod sho." These are the same words that Alisoun used after that famous kiss in "The Miller's Tale."

${ }^{3}$ The convent of the Observentines was at Stirling. Mackay, p. xcvi.

4.W. Baxter, William Dunbar: A Biographical Study (Edinburgh: Oliver and Boyd, 1971), p. 22.

5Denton Fox, "Dunbar's 'The Goldyn Targe'," ELH, 25 (1959), 331-33.

6ois A. Ebin, "The Theme of Poetry in Dunbar's 'Goldyn Targe'," The Chaucer Review, 7(1.972), 147-59. 


\section{CHAPTER III}

The second period of Dunbar's poetic growth consists of those poems which are numbered seventeen through sixty-four. This period, like the preceding period, is set off as a distinct unit by the characteristics which are unique to it. In this period Dunbar's poetry grew to its full maturity. It is here that Dunbar refined the raw material of his first period, leaving behind many of the traditional aspects of his first works. Over half of the poetry of this period concerns his own financial position and the life of the court and of his fellow Scots. Some of these poems are Dunbar's most vehement, and it is in these that he refines hls alliterative abilities to such an extent that his vehemence and sense of injustice seen to pour forth in one continuous stream. Not all of Dunbar's poems axe, however, so serious. He wrote several satires and humorous poems in this period, as well as six love poems. Here alliteration is used to achieve a lighter effect. In addition to alliteration, many of his poems, both comic and serious, demonstrate his refinement of the refrain line as one of his most effective poetic devices as well as one of his most favored. I have previously referred to this period as Dunbar's period of experimentation; refinement is part of that experimentation. This refinement involves a "sharpening" of Dunbar's poetic vojce. His poetry increases in quality in every way that poetry can. He decreases the number of his stanzaic forms, but those which he keeps he explores and developes with an increasing firmness and clarity of statement and with a. depth of emotion not found in 
his first period. The poems of this period seem, in the context of the body of his work, to be the most natural, the least artificial of his poems.

The individual poems fall chronologically into thematic groups (see chart). The period begins with a cluster of vituperative poems and ends with a pair of vituperative poems. The block consists of those poems numbered $18,19,21,22,26,27,28,29,30$ and 34 plus a subsidiary pair of poems numbered 46 and 49. In the same way his moral and satiric themes fill in the mid twenties and forties, and his humorous and laudatory poems are all in the upper thirties. Dunbar's love poetry falls Into another block numbered $40,41,42,43$, and 44. The remaining twelve poems are all precatory and form one rather large group at the end of this period, which begins with poem number 50 and includes all of the poems up to and including number 64 . Not all of these blocks are large, but those that are, such as the vituperative, the love, and the precatory groups, demonstrate a new thematic depth in Dunbar's poetry. This depth Is visable on both the general level and the level of the individual pcem. On the general level he achieves depth by the frequent re-exploration of a given theme. Thus, in his precatory poems his frequent repetition of his need for a benefice in the poems "To the King, quhen mony Beneficecs vakit" (非2) and "To the King, after the Benefices were filled up" (\$54) and his catalogues of courtiers unworthy of recelving the King's aid in "To the King, Dunbar's Complaint" (韭57) and "To the KIng, Dunbar's Remonstrance" (非58) produces the same effect on the whole group of precatory poems as one of his extensive catalogues does within an individual poem. By way of example I cite a passage from "To the King, Dunbar's Remonstrance": 
Bot ye sa gracious ar, and meik, That on your hienes followis eik. Ane uthir sort, more miserabill, Thocht thai be nocht sa profitable:

Fenyeouris, fleichouris, and flatteraris;

Cryaris, craikaris, and clatteraris;

Sonkaris, grouksris, gledaris, gunnaris;

Monsouris of France, gud claret-cunnaris;

Innopportoun askaris of Yrland kynd;

And meit revaris, lyk out of mynd. .

This catalogue impresses upon the reader the large number of "hangerson" that inhabit the court by dint of the number of descriptions that Dunbar is able to summon up for them. Certainly, he could have indicated that the court was full of such people in a more concise fashion but in doing so the overwhelming effect of his catalogue would have been 1ost. By including a catalogue Dunbar is able to present each and every malefactor in a way that makes him more real, more of a present threat, than a concise generalization would be able to do. In addition, by enumberating the many kinds of malefactors present, he gives his general view of money-seekers more depth of meaning precisely because he indicates all of the kinds of money-seekers that are present in the court. Here the whole is greater than the sum of its parts, for by cataloguing, Dunbar creates an effect with each additional type of "hanger-on" as well as an over-all effect with the catalogue as a whole. This same effect is apparent in the tody of Dunbar's precatory poems where each poem is an item in Dunbar's catalogue of appeals for some sort of royal recompense. Each poem is its own unique appeal, and thus he achieves the thematic depth that I have been speaking about. This perfod is the most crucial to Dunbar's stanzalc development. During it he tries the four forms that he has not used previously. In the latter part of this period, however, he abandons many of these 
forms. To be more specific, Dunbar has tried all of his major forms after his 27 th poem, "The Birth of Antichrist". The only forms that he has not.used by that time are 1) the octet, which he uses only in "The Flyting of Dunbar and Kennedie" (非), 2) the four-foot octet of which he uses only in "The Testament of Mr Andro Kennedy" ("36), and 3) his refrained sextet which he uses in two poems, "The petition of the Gray Horse, Auld Dunbar" (非99) and "Of Iufe Erdly and Divine (非5). The six-line refrained stanza, is the last form that Dunbar tries, and thus with poem number 59 Durbar has written in all of his sixteen forms. He no longer uses short couplets, triolets, tail rhyme, alliterative verse, refrained septets, eight- and nine-line stanzas without refrain and the four foot octet. This elimination results in a refinement of form parallel to his refinement of theme. It is apparent, then, that Dunbar gradually came to prefer stanzaic and refrained forms over. others. Indeed, his last period contains nineteen refrained poems out of the thirty-seven works which comprise it. In this second period twenty-seven of the forty-eight poems are refrained. The short refrained form is most characteristic of Dunbar's style, a style that develops in this period. Most characteristic of this style is Dunbar's use of the non-constant refrain, a refrain in which frequentiy only the last word or two is retained from stanza to stanza. Such a variation is not orfinal with Dunbar, but he brings it to its height of refinement in the wediaeval period. He does not, however, use non-constant or varied refrain exciusively. Several of his poems do have constant refrains, among these his only true ballade, "Be ye ane Luvar" (非1). In general, however, the varied refrain has predominance over the constant. While it is true that there is a definite progression in this 
period and the next toward an almost exclusive use of refrained stanzaic forms, Dunbar does not entirely eliminate non-refrained verse. Twenty-one of the poems in this second period do not have refrains.

I have discussed the thematic and stanzaic patterns which are most characteristic of this period in Dunbar's development. It now remains to demonstrate particular occurrences of these patterns.

The largest number of poems in this period may be categorized under the title "Poems of Righteous Indignation". These are Dunbar's precatory and vituperative poems, and they concern the decay of court and kingdom as Dunbar sees it, taking the form of verbal castigations directed at every social level. Occasionally his invectives are directed at one individual, as in "Against Treason" (非18), which concerns the treason of Donald Owre in $1503,{ }^{2}$ but more often they are directed at an entire social class, city, or trade. An excellent example of this latter type is his poem "Satire on Edinburgh" (\#22), in which he denounces the merchants of Edinburgh for allowing their city to develop a poor reputation:

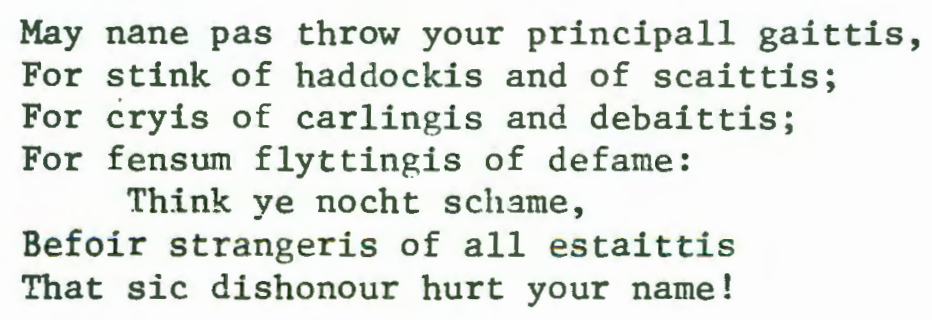

His most vehement vituperatives generally take the form of a wideranging catalugue of kinds of moral decay. The best example of this form is "The Dream" (非8). Also called "A General Satire", it is written in refrained cinquains and exhibits many of the poetic devices that were observed in his early poetry. In this poem those devices are incorporated more skilfully; their use is less evident. 
As the title implies, "The Dream" is presented as a dream of the poet. This dream format is found in many of Dunbar's poems but this dream is not terminated as is the dream in most works of a similar nature. In effect this structural device undermines the dream format. Dunbar does not remind his readers that he is merely relating a dream by including an "awakening" at the poen's end. Dunbar's refusal to include the coventional "awakening" scene, coupled with his extensive catalogue of kinds of moral decay within the country, serves to suggest that the dream is a reality. As in "The Golayn Targe" of the first period, Dunbar is using a conventional device, the dream format, to present his own ideas, but in this poem he is relying less heavily upon the apparatus of the conventional form. He does not dwell on the dream setting of his poem; he devotes only the first line of the first stanza to it and then proceeds to his consideration of the state of the Kingdom:

Devorit with dreme, devysing in my slummer, How that this realme, with nobillis owt of numner, Gydit, provydit sa mony yeiris hes bene; And now sic hunger, sic cowartis, and sic cummer Within this land was nevir hard nor sene.

Here we find the same cataloguing technique that was seen in the first period, but this list functions more complexly than the earlier ones. It is composed of balanced units, each reflecting and modifying another unit of the same or a subsequent 1ine. In effect the unfts are equated; in the first line it is as if the "maisteris" were equated with the "guckit clerkis" and both the "maisteris" and "clerkis" equal the "mony westaris to God and all his warkis". Furthermore, each of these is an item in the overall catalogue and therefore each affects and modifies the items in subsequent stanzas. It is this interaction between the 
items that creates the flow of the poem. If it were not for this interaction the poem would be static, for the poem itself does not involve a progression of thought. If one were to abstract the basic ideas of the poem one would find that it is simply a statement that the poet had a dream and that in that dream he saw ail of the causes of the kingdom's decay. Dunbar does not offer any explicit solution to the decay. It is tempting to speak of this poem in terms of painting because in many ways the poem is a picture; it is a portrayal. of the society's decay which does not need the author's comment. A glance at the work is all that one really needs to see what Dunbar was pointing at. Of greater interest is the manner in which he presents that picture. Why is it so vivid? What makes an otherwise dull list interesting?

I have already indicated some of the devices which create this vivid image. Parallel verbal structure is the most prominent poetic device in the pcem and is a major factor in the tone. Another factor contributing to the tone is the catalogue of aspects of moral decay. Each aspect reinforces and expands the overall theme and combined with the parailel structures which pull the various aspects closer together, creates the dominant tone. Another unifying device is the constant refrain line, "Within this land was nevir hard nor sene", which serves to re-emphasize the degree of the kingdom's decline. Beyond this the efiect of the refrain on the unity of the poem is hard to define. It is almost like a vertical Iine in a painting that is repeated in the lines of a doorpost, a building, and, on the other side of the picture, In a wirdow or in the posture of a figure. By repetition it adds to the overall unity of the painting, but it is not in itself the unifying factor. Rather, it is a referent, a familiar line at which the viewer's 
eye momentarily stops before continuing to scan the picture. Thus, just as a vertical line causes a visuai pause, so the refrain line produces a slight vocal pause before the reader continues to the next stanza. While repetition of the line creates an added sense of unity to the poem, it also contributes to the pleasure of the reading through the same process. In a sense it serves as a familiar base from which he returns at the end of it. This use of repetition is particularly important in studying Dunbar's verse because the refrain is such a basic element of his writing.

Tied into the refrain is another device which supplies a unifying pattern to the poem. This device is his rhyme scheme. As I have said, the poem is in the form of cinquains, the fifth line of the cinquain being the refrain. Dunbar uses a pattern of $a, a, b, a, b$, to rhyme these stanzas and in so doing ties the whole poem together with the "b" rhyme. Because he uses a constant refrain, the "b" rhyme is the same throughout. The refrain line is tied into the body of the stanza because of the audial conrection that a thyme makes. This is perhaps a subconscious factor of unity; one does not normally see the rhyme of a poem as much as sense it, as in a recurring melody. Such a rhyme scheme is an extension of the refrain and affects the work in the same way by providing a familiar base from which the rest of the stanza extends. The refrain functions as the point of perspective, the focal point for each stanza. It is the place to which each of the stanzas returns, aided by the "b" rhyme which points to it.

Two other devices also contribute to the tight unity of "The Dream." These are alliteration and internal rhyme. In the fourth stanza, cited above, there is ar internal rhyme scheme of $a^{1}, a^{1}, b^{1}, b^{1}$ 
in the first four lines of the cinquain; this scheme holds the lines together fin a way that the end rhyme does not. The "a" rhyme unites the first, second and fourth IInes while the third is related to the fifth by means of the " $b$ " rhyme. The internal rhyme on the other hand, while it still unites the first two lines with the "a" rhyme, ties the third and fourth with the " $b$.". This pattern is found in all but the first stanza of the poem, and is a further step in its overall unity. "The Dream" is only lightly alliterated but when alliteration is used It serves to pull together the two halves of a line, as in "So mony maisteris, so mony guckit clerkis" (1.16), by creating a tonal bridge between the two halves.

All of the poetic devices that I have spoken of have one overwhelming effect and that is to unify the work. In concert these devices produce a harmonious whole out of the disparate items of the catalogue and provice a substructure of interrelationship. "The Dream," dating from early in the second period, contains characteristics of both the first and second periods. As in the poems of the first period, the poet appears at the beginning to provide an occasion for the telling of the poem's story. "The Dream" is unlike first period poems in that while the people and actions described in it are sometimes humorous, they are not presented simply to be laughed at as in "Ane Brash of Wowing." There is an implied moral judgement in this poem which is evidenced by the narrator's selection and juxtaposition of words. This implicit judgement is an early development towards the poem in which Dunbar directly expresses himself. There are several poems, "Lady So1istaris at Court" (非20) and "Aganis the Solistaris in Court" (非1), for instance, in which opinions are directly expressed, but in such poems 
the opinions seem to be those of a general group of people. While that group of people most probably includes the speaker, he is not explicitly the source of the opinions. Dunbar here is speaking in his public voice. Dunbar's public voice yields later in this period to his personal voice, but each poem in the chronology does not, of course, represent a slightly more advanced aspect of this process. The shift from public to personal voice is evident only as a general trend. The poem entitled "To the King, Dunbar's complaint" (\$57) expresses a vein of righteous indignation similar to that of "The Dream," in that it is basically a catalogue and its main concern is with decaying conditions, in this case within the court. These similarities aside, the two poems differ greatly. "The Complaint" a precatory poem in short couplets, presents an argument whose purpose is to convince King James to aid his nobles and more specifically Dunbar himself. It begins with the direct statement that "Complane I wald, wist I quhome till ... Off wrangis, and of gryt iniuris,/ That nobillis in thar dayis indures" (1.1-10). From this he enters into a long catalogue of the "Crawdones, couhirttis, and theiffis of kynd" (1.22) who inhabit the court and have usurped the places and honors which ought to belong to the nobles, among whom Dunbar places himself. He then suggests a consideration of the humiliating position of the nobles forced to sit at a lower place "at tabell" while men "Quhilk natur maid to beir a pak" (1.58) sit above them. Having presented this picture he adds his appeal which I quote in full:

Thairfoir, 0 prince, maist honorable!

Be in this mater merciabill, And to thy auld schervandis have an $E$, That lang hes lippinit into the; Gif I be ane of thay my sell, Throw all regiones hes bein hard tell, of quhild my wryting vitnes beris; 
And yet thy danger ay me deiris:

Bot eftir danger cumis grace,

As hes bein herd in mony place.

Certainly, this appeal is well calculated and it provides a continuity and flow of thought. His argument is supported by the use of poetic devices, however, which help to emphasize it. In the second section of the poem (11nes 15 through 39), he uses a low level of language to describe the people who have humiliated the nobles of the court; this low language is supported by heavy alliteration which makes Dunbar's catalogue a steady stream of vituperation:

Bot fowl1, jow-jowrdane-hedit jevellis,

Cowkin-kenseis, and culroun kewellis;

Stuffettis, strekouris, and stafiche strummellis;

Wyld haschbaldis, haggarbaddis, and hummellis; . .

Dunbar uses this level of language and the alliteration only in this section of his "Complaint" underlining the distaste that the words express by setting them off from the other sections of the poem, which contain highly alliterative lines and a higher level of language.

Such poems as the two that I have just discussed, indeed the precatory and yituperative poems in general, while they aid in demonstrating the development in Dubnar's style, represent only one facet in the poetic body. They are not necessarily attractive poems, in the sense that a poem attracts a reader to return to it over and over again. They are perhaps of more value to an historical critic or to a critic attempting to reconstruct Dunbar's biography.

A more attractive aspect of Durbar's work is found in those poems which may be categorized as moral poems. There are five such poems in this period, "Against Swearing" (非3), "To the Quene" (非4), "Lament for the Makaris" (非1), "My heid did yak yesternicht" (非32) and "Quha wil1 behald of Luve the chance" (非5). Of the five poems in this group the 
first retains the drean format already seen in several of his poems. The other four are direct, first person statements. The first poem tells of a dream in which the narrator sees the devil tempting people with oaths "of crewaltie." He then describes how the devil passed through the town capturing souls with his bait. (Interesting in this poem is that each stanza depicts a different type of person being tempted by the devil. It strikes me that this is an expansion of the catalogue device in which each item is presented in a full stanza rather than in a single line.) His refrain line represents the devil's words to each of the tempted souls. "Renunce thy God and curn to me." The second poem, "To the Quene," takes a lighter moral tone. Addressed to the queen directly, it tells of her men's attempts "Off Wenus feest to fang ane fill" (1.7) and includes in the final stanza a warning to young men to avoid harlots and "that perellouss play,/ That men callis libbing of the pockis" (1.34-35). "Libbing of the pockis" is the last part of his variable refrain and refers to a cure for "lues venerea."2 Neither of these poems has the impact and emotion of the third poem, which is probably his most popular. "The Lament for the Makaris," subtitled "Quhen he was seik," is in the tradition of the "ubi sunt" poem of Villon. Dunbar begins his poem with an image of himself in poor health:

\footnotetext{
I that in heill wes and glaidness, Am trublit now with gret seiknes, And feblit with infirmitie; Timor Mortis conturbat me.
} 1.4

From this realistic image he goes to a more general statement of the world's transitory nature; he then lists some of the people whom death affects and some of the "cures" which do not affect it, and finally 
turns to a list of the poets, "makaris," who have gone before him. This list begins with Chaucer and ends with the supposition that Dunbar will be Death's next victim. Immediately following this conclusion is the moral of the poem:

\footnotetext{
Sen for the deid remeid is non, Best is that we for dede dispone. Eftir our deid that lif may we; Timor Mortis conturbat me.
}

Seemingly simple, "The Lament for the Makaris" is one of Dunbar's most sophisticated poems. It is a careful balance of images and poetic devices whose interrelationship provides a strong unity within the poem without interrupting its flow or obfuscating its meaning. Poetic devices are used here more sparingly than in other poems, such as "The Dream," and when used they are less obvious. An example is his use of parallelism. Within the context of the poem Dunbar shifts from the present tense to the past, from the past back to the present, and finally from the present to the future. Primarily he does this by changing the tense of the word "takis" in the repeated phrase "He takis." In the three stanzas between lines 21 and 32 he repeats this phrase three times, once in each stanza but with the variation that the second stanza supplies the phrase "That strang unmercifull tyrand" for the pronoun "he." Between the 13th and 21st stanzas this phrase changes to the past tense form "he has tane" which he uses three times and which he varies with such parallel forms as "He has reft," "He hes done petuously devour" and "he has done roun." He then changes to the present tense in the 23rd stanza with "And he has now tane, last of aw." Finally he moves to the immediate future in the 24 th stanza:

Sen he has all my brether tane, He will naught lat me lif alane, 
On forse I man his nyxt pray be;

Timor Mortis conturbat me.

A less frequent use of parallelism is found in the 8th stanza, in which he combines a parallel verbal structure with a parallel set of images:

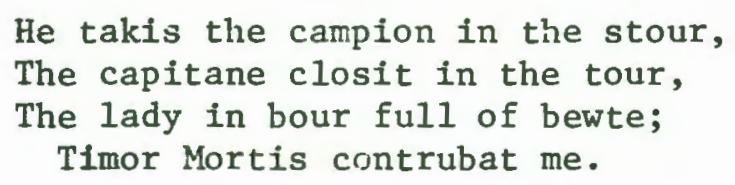

Notice that the parallel structure underlines the image of death taking each of his victims "in" a place and that by uniting these three images the idea of the universality of death is emphasized.

Dunbar uses rhyme in a similar manner. "The Lament is in the form of quatrains with a constant refrain. His rhyme scheme is $a, a, b, b$, and, as in "The Dream," the constant refrain causes the " $b$ " rhyme to be consistent throughout the poem. This has the same unifying effect that it has in "The Dream." In addition to this use of rhyme Dunbar uses internal rhyme in one stanza of "The Lament." In the 10th stanza he rhymes the second words of both the first and second lines, the words "magicianis" and logicianis." He then adopts the same rhyme for the "a" end rhyme of the 11th stanza, which unites the stanzas audially.

Isolating these poetic devices does not demonstrate the overall unity. of the poem as it did in "The Drean," which depends more upon poetic devices for its unity than on a process of thought, as does "The Lament." "The Lament" is a kind of ritual consideration of the advent of death. I use the word ritual for two reasons. First, the poem runs the course of a typical consideration of death. That is, it begins with a consideration of the situation, the poet's illness, moves to a reflection upon the transitory and futile nature of 11fe, and then considers 
death's effect upon "all Estaitis." From this general meditation the poet lists particular people who have died. The list brings him back to a consideration of this own death and the decision that the only solution open to him is to prepare for death that he might have an afterlife. His is a typical pattern of a meditation on death. Secondly, as J.W. Baxter notes in his William Dunbar, the refrain line, "Timor Mortis conturbat me," is a line from the office of the Dead. ${ }^{3}$ Because of this religious association and because it is in Latin rather than Scots-English, the line stands apart from the rest of the stanza and acts as a response (as in the "responsio" of the Mass). The tone of "The Lament" is more personal than that of any poem yet encountered. It is personal because, while the poet meditates upon death as it concerns us a1l, he meditates movingly on his own. This personal tone appears more frequently in the later poems.

The fourth moral poem of this period, "My Heid Did Yak Yesternfcht," although much shorter, is similar to the "The Lament." Because of its brevity, I cite it in full:

My heid did yak yesternicht, This day to mak that I na micht,

So sair the magryme dois me menyie, Perseing my brow as ony ganyie, That scant I luik may on the licht.

And now, schir, laitlie, eftir mess, To dyt, thocht I begowthe to dress,

The sentence lay full evill till find,

Unsleipit in my hei behind, Dullit in dulness and distress.

Full oft at morrow I wpryse, Quhen that my curage sleiping lyis, For mirth, for menstrallie and play, For din, nor danceing, nor deray, It will nocht walkin me no wise. 
Like "The Lament" this poem begins with a description of the poet's disability, in this instance a headache, which may seem to be a trivial subject for a poem. It is not trivial after Dunbar gets through with 1t. He explains that the headache has so troubled him that he cannot write or look "on the Licht" and the sentences lie in the back of his head "Dullit in dulness and distress." The normally minor malady has stifled his creative process which, as the parallel reference to light Indicates, is his life. In his most personal voice Dunbar examines the Implications of this small occurrence and expands them until they have universal significance and by so doing he creates a poem that prefigures the Renaissance in subject and tone. In three cinquains Dunbar progresses from the past of "yesternicht" to the now of the second stanza, to the future of the "morrow" of the third, showing in each instance how the headache disturbs him. By placing himself in the middle of this time referent Dunbar creates a subtle inversion in which the headache surrounds him rather than him (his body) surrounding it. He externalizes it and it becomes an alien power, as fate or the vagaries of nature, exercising its force over him. It becomes an object and he deals with it in objective terms. Arthur Moore notes this in The Secular Lyric in Middle English:

The historical interest of the poem rests on the assertion of purely personal emotion as fitting matter for poetry, the cholce of a subject altogether trivial, and the expansion of theme by objective, non-narrative methods.

While the subject matter and the intensely personal tone distinguish this poem from the majority of Dunbar's work, it is not uncharacteristic of his poetic voice and still contains those attributes which distinguish his work from any other. 
Different in both form and content is his last moral poem of this period entitled "Quha will behald of Luve the chance" (非5). This is one of the six poems of the second period which are in the form of tailrhyme. In this poem the tail-rhyme is in the fourth and eighth lines of the stanza, forming a rhyme scheme of $a, a, a, b, a, a, a, b$, with the " $a$ " and " $\mathrm{b}$ " rhymes constant throughout. Only three stanzas long, the poet tells his view of love in the first and second stanzas:

Quha will behald of luve the chance, With sueit dissauying countenance, In quhais fair dissimulance May none assure:

Quhilk is begun with inconstance, And endis nocht but variance, Scho haldis with continwance No scheruiture.

Discretioun and considerance Ar both out of hir gouirnance; Quhairfoir of it the schort plesance May not indure;

Scho is so new of acquentance, The auld gais fra remembrance; Thus I gife our the obseruanss of luvis cure.

and draws his moral in the third:

It is ane pount of ignorance To lufe in sic distemperance Sen tyme mispendit may avance No creature;

In luve to keip allegance

It wal als nyss an ordinance,

As quha wald bid ane deid man dance, In sepulture.

of the five moral poems of this period, "Quha will Behald" is the only poem to deal with the theme of love. Chronologically, it comes after the first five of the six love poems, implying that Durbar was unsuccessful and embittered in love. Be this as it may, he does renounce the practice of love. The reason for his renunciation, given in the 
third stanza, expresses the moralistic tone of his decision with the use of the words "ignorance" and "distemperance" and especially with the use of the image in the last two lines, one of his characteristic twists, "As quha wald bid ane deid man dance, /In sepulture," which strikes a tone that is almost anti-Christian, implying that love's practitioners are also anti-Christion. There are then two levels to the poem. One level is the disappointed lover renouncing love as impossible to practice. The other is the moralist who is renouncing the practice of love because it "may avance/No creature" to heaven. By incorporating both levels into the poem, Dunbar reflects both the courtly love tradition and the position of the Church towards "carnal" love.

In a less moralistic vein are Dunbar's satires of this period. These three poems, "Lady Solistaris at Court" (" 20), "The Dance of the Sevin Deidly Synnis" (将33) and "Of Sir Thomas Norray" ("\$48), depend upon humor for their effect. "The Dance of the Sevin Deidly Synnis" concerns a dream that the poet had in which the devil called for a dance "Aganiss the feist of Fasternis evin" (1.8). The dance is led by Pryd, the first of the seven deadly sins. Following him are the other deadly sins, Yre, Invy, Auaryce, Sueirness, Lichery, and Gluttony. These having danced past "Mahoun," the devil, calls for "a Heleand padyare." The High1ander "Makfadyane" is brought Eorth, he sounds the "correnoch" and is immediately surrounded by "Erschmen." Dunbar describes the pageant in these terms:

Thae tarmegantis, with tag and tatte, 1.115 Ffull lowd in Ersche begowth to caltter, And rowp lyk revin and ruke; The devill sa devit wes with thair yell; That in the depest pot of hell

He smorit thame with smuke. 
The results of this pageant provide a comic relief to the otherwise grim dance macabre of the seven deadly sins. The language of "The Dance" is 1ow; because of its use in association with the heliish images of the dancing figures it is particularly striking. The conjoined images and language result in some of the most strident vituperation that Dunbar produced:

Nixt him in dans come Cuvatyce, 1.55

Rute of all evill and grund of vyce, That nevir cowd be content; Catyvis, wrechis and okkeraris, Hud-pykis, hurdaris and gadderaris, All with that warlo went:

Out of thair throttis thay schot on udder Hett moltin gold, me thocht a fudder, As fyreflawcht maist fervent;

Ay as thay tomit thame of schot, Ffeyndis fild thame new up to the thrott 1.65 With gold of allkin prent.

Only by dint of the Highland pageant in the last two stanzas does the poem achieve satiric rather than purely vituperative statement. "The Dance" is closely related to the vituperative and precatory poems in tone, content, and style. .

In contrast to the vituperative, the moral, and the satiric, all of which I have designated poems of righteous indignation, there are categories of poems which are lighter in tone. These are the humorous, the laudatory, and the conic poems. Of these three, the laudatory poems are the least characteristic of Dunbar's second period. In general they are hyperboliz: whatever the subject of his encomium, it it described in the superlative terms that are "traditional in the mediaeval poetry of praise. Northrop Frye notes in his Anatomy of Criticism that "invective is one of the most readable forms of literary art, just as panegyric is one of the dullest." 4 I cite a stanza from "To the Quene" (非17) which 
is indicative of the height of hyperbole that Dunbar reaches in such verse:

$$
\begin{aligned}
& \text { Gladethe thoue Queyne of Scottis regioun, } \\
& \text { Ying tendir plaunt of plesand pulcritude, } \\
& \text { Fresche flour of youthe, new germyng to burgeoun, } \\
& \text { Our pearle of price, our princes fair and gud, } \\
& \text { Our chairbunkle chosin of hye Imperiale blud. } \\
& \text { Our Roys Riale, most reverent under Croune, } \\
& \text { Joy be and grace onto thi Selcitud! } \\
& \text { Gladethe thoue Queyne of Scottis regioun. }
\end{aligned}
$$

The language of this poem represents the opposite of the low language

found so often in Dunbar. Here he catalogues Margaret's virtues, metaphorically equating her with a pearl, a diamond, and a rose. Such a list of metaphors, foreign to the modern sensibility, was designed to indicated the superior qualities of the lady by comparing them to objects, plants, and animals superior among their own kind. Thus Margaret is "moir deir" than a diamond, the most precious of gems; she is "resplendent" as the rose, the beautifully colourful of flowers. Leo Spitzer explains the convention in his essay "Explication de texte' Applied to Three Middle English Poems:"

That the poet sees his Lady as a paragon means that he singles out for praise not individualistic traits of personality but qualities of objective validity which she possesses to a superlative degree (her uniqueness consisting in the potentiated generic). 5

Dunbar's three humouous poems of this period are "Of a Dance in the Quenis Chalmer" (非), "The Testament of Mr Andro Kennedy" (非6) and "Of ane Blak-Moir" ("⿰37). "Of a Dance" relates a dance held in the Queen's chamber in which Dunbar himself is seen to participate. Each stanza depicts a different member of the court demonstrating his dancing skills while the others comment and snicker:

Than cam in the Maister ALMASER, 
His hippis gaff mony hiddouss cry. John Bute the Fule said, "Wa es me!

He is bedirtin, -Fy! fy!"

A mirrear Dance mycht na man se.

Done in refrained septets, this poem is highly alliterated, like many of the vituperative and precatory poems, and consequently it has a rolling rhythm which simulates the quick succession of dancers demonstrating their abilities. Heightening the comic effect of the poem is the ap-. pearance of Dunbar as a dancer separate from the persona telling of the events in the Queen's chamber in the fourth stanza (Iines 22-28). He first compliments himself as the finest dancer on the floor and then describes how he danced so well that "He hoppet lyk a pillie wantoun" (1.25). His initial grace does not, however, excuse him from courtly laughter, for two lines later he says of himself that "He trippet, quhill he tint his pantoun" (1.28).

The second humorous poem of this period, "The Testament of Mr Andro Kennedy," is in macaronic verse. "The Testament" is a will of Andro Kennedy in which he describes his last wishes. In some stanzas after each line of his will a line in Latin puts the lie to what he has just said; in other stanzas the process is reversed: his Scots-English is the comic line for the "straight line" of Latin. One stanza will suffice to indicate this format:

Nunc condo testamentum meum, I leiff my saul for euermair, Per omnipotentum Deum, In to my lordis wyne cellitir;

Semper $i b i$ ad remanendum, Quhi1 domisday, without disseuer, Bonum vinum ad bibendun, With sueit Cuthbert that luffit me neuer.

Only one other poem uses Latin in this manner, "The Dregy" (非) which uses Latin to parody the Mass for the Dead. The Latin of "The Dregy" 
is not macaronic, however, but j.s divided into discrete units separated from the Scots-English. The macaronic use of Latin in "The Testament" parodies the seriousness of a will as well as its writer. Therefore, while the use of Latin in humorous verse is not new to Dunbar, the use of macaronic verse is, which adds still another facet to his manyfaceted style.

"Of ane Blak-Moir" is of more historical interest than literary. In refrained cinquains it tells of a special tournament held in honor of a black servant. The prize in the tournament, which as Mackay notes, was probably held in June of $1507,{ }^{5}$ was a kiss from "My ladye with the mekle lippis." The penalty to the losers on the other hand, was as follows:

And quhai in felde receawes schame, And tynis thair his knychtlie name, Soll cum behind and kiss hir hippis, And newir to wther confort clame: My ladye with the mekle lippis.

Dunbar's amatory poems fall into one group chronologically, ending with a renunciation of love in "Quha will behald of Luve the chance" (\$45). Of these five, "To a Ladye" (\#40), "Be ye ane Luvar" (非1), "Fane wald I luve" (非2), "Gif ye wald Luve" (非3) and "To a Ladye, Quhone he list to feyne" (非4), the first is undoubtedly the finest, because it exhibits all of the best qualities of Dunbar's style without any of the excesses of usage or repetition. I cite it in full:

Sweit roiss of vertew and of gentilnes, Delytsum lyllie of everie lustynes, Richest in bontie, and in bewtie cleir, And everie vertew that is held most deir, Except onlie that ye ar mercyless.

In to your garthe this day I did persew, Thair saw I flowris that fresche wer of hew; Baithe quhyte and reid moist lusty wer to seyne 
And halsum herbis upone stalkis grene;

Yit leif nor flour fynd could I nane of rew.

I dout that Merche, with his could blastis keyne, Hes slane this gentill herbe, that I of mene;

Quhots petewous deith dois to my hart sic pane

That I waid mak to plant his rute agane,

So confrontand his levis vnto me bene.

The poem begins in the hyperbolic fashion of laudatory verse, attributing all virtues to the lady. This praise, however, seems to be undermined in the fifth line of the initial stanza by the comment that she is "mercyless," as in the courtly love convention. The poet then describes a venture into the Lady's garden, where he finds many beautiful flowers but can find no "rew." This description, a metaphoric statement about his lady, suggests that the double correlation of rue-a bitter herb, on the one hand, and care or concern on the other--apply also to the lady's mercy. The parodox of the rose of virtue which is also the lily of pleasure is supported by the tension of the mercy which is on one hand the requirement of love and on another divine grace.

One other love poem stands out as distinct from other works and that poem is "Be ye ane Luvar" (\$4.1). A concentrated use of one poetic device, head rhyme, distinguishes it from the others. The poem itself Is a list of rules for a lover, the rules presented in three octets, the lines of which all begin with the word "Be:"

Be ye ane luvar, think ye nocht ye suld

Be weill adwysit in your gouerring?

Be ye nocht sa, it will on yow be tauld;

Bewar thairwith for dreid of misdemyng.

Be nocht a wreche, nor sherche in your spending,

Be layth alway to do amiss or schame;

Be rewlit rycht and keip this doctring,

Be secreit, trew, incressing of your name. 
Containing, as it does, forty-eight poems, this period is the largest of the three. It reflects the widest variety of Dunbar's work. Despite this variety there is a unifying element not apparent in the first period, a personal voice by means of which Dunbar extends to a11 levels of his society, taking such forms as vituperation, satire and humor. His critical attitudes do not preclude love poetry and the obvious joy expressed in one or two of the comic verses. This personal eilement becomes apparent through a gradual change in Dunbar's style. During the first part of this period, also, there is little correlation between theme and stanzaic form. Near the end of this period a correlation begins to develop and after the fifty-ninth poem, his stanzaic range diminishes to only eight forms, while after the sixty-fourth poem, his thematic range is limited to two major forms. 


\section{FOOTHOTES TO CHAPTER III}

1Mackay, p. clxi.

2 Walter Gregor, Notes and Glossary to The Poems of William Dunbar ed. John Sma11, 1st ed. (1893; rpt. New York: AMS Press, 1973), 111 , 287.

3 Baxter, p. 135 .

${ }^{4}$ Northrup Frye, Anatomy of Criticism: Four Essays (Princeton: Princeton Univ. Press, 1957), p. 224.

${ }^{5}$ MacKay, P. 1xxi. 


\section{CHAPTER IV}

Because it is dominated by moral and religious poetry, the third period stands apart as the most distinct and cohesive phase of Dunbar's development. Only six of the thirty-seven poems do not fall under either the category of moral or religious verse; two of the six are vituperatives and the other four are laudatory poems. The remaining thirty-one poems divide into seventeen moral and fourteen religious poems. Given the relatively large number of poems in this period, a reduction in themes and forms suggests an effort on the part of the poet to express himself in one or two areas alone. The effort on Dunbar's part had mixed results, producing several poems which achieve a greater depth and sonority than anything he has yet done, but in the main ylelding a series of poems lacking in freshness and variety from the point of view of the modern sensibility. This criticism applies to the moral as well as the religious categories; both contain some exceeding1y good poems and a large number of less significant works. In general the better poems, whether moral or sacred, strike a personal note whereas the lesser poems are, as Mackay notes in his introduction to the STS edition, "all in one manner." 1

Chronologically, the poems of this period fall into very tight groups, which are seldom interrupted by poems from another category. The first of these groups is the category of moral poetry. Numbers $65,66,67,69,70,71,72,73,74,75,76,82,84,85$ and 100 in the chronology are all moral poems. These poems concern one or both of 
two subjects: the variability of this world or God's steadfast love In this world and the next. When he concerns himself with the world's changeability, Dunbar's attitude is often that one must accept the world's flux and maintain a cheerful attitude in spite of it. The poems "Man, sen thy Lyfe is ay in Weir" ("13) and "Fu11 oft I muss" (\#66) reflect this attitude in their respective refrain lines, "Thyne awin gud spend quhill thow hes space" and "For to be blyth me think 1t best," Perhaps the best example of this attitude is the poem "Meditatiour in Wyntir" (非75), written in cinquains, which in many respects is Dunbar's highest achievement in the use of alliteration and rhythm for the purpose of creating a particular tone. It begins with a description of the weather, which has stifled his writing ability and troubled his spirit:

In to thir dirk and drublie dayis, Quhone sabill all the hewin arrayis, With mystie vapouris, cluddis and skyis, Nature all curage me denyis off sangis, ballattis, and of playis. 1.5

Quhen that the nycht dois lenthin houris With wind, with haill, and havy schouris, My dule spreit dois lurk for schoir; My hairt for languor dois forloir, For laik of symer with his flouris.

The deep resonance of these lines, created by the alliteration and the liquid and nasal consonants, immediately sets the mood for the rest of the meditation, which turns next to the poet's state of mind:

I walk, I turne, sleip may I nocht,

I vexit am with havy thocht;

This warld all ouir I cast about, And ay the mair I am in dont, The mair that I remeid have socht.

The poet's disturbed state of mind is captured through the change in rhythm in the first line and the contrasting second line, emphasizing 
by the variation in rhythm his frustrated activity. He is then "assayit on everie syde" (1.16) by personifications of his attitudes, such as "Dispair," "Patience," "Prudence," "Age," and finally "Deid" "who castis up his yettis wyd" (1.36) and says "Thair is nane vther way besyd" (1.40). Oppressed by these thoughts, the poet explains that he has not remembered all day how good it is to be alive and "How glaid that ever I dyne or sowp" (1.45). This statement leads him to his final consideration which characteristically reverses the tone of the poem in an enthusiastic renunciation of winter for the anticipated joy of summer:

$$
\begin{aligned}
& \text { Yit, quhone the nycht begynnis to schort, } \\
& \text { It dois my spreit sun part confort, } \\
& \text { off thocht oppressit with the schouris. } \\
& \text { Cum, lustie symmer! with thy flouris, } \\
& \text { That I may leif in sum disport. }
\end{aligned}
$$

The sudden reversal invites two levels of interpretation. On one level he is simply rejecting the gloom of winter for the anticipated pleasure of a languorous summer, but on another level he may be rejecting the gloom of life for, the joy of after life. In either case, although they are not mutually exclusive, this optimistic twist changes the direction of the poem in a manner which is distinctly Dunbar's. He does not express this even noted optimism in all of his moral poems, however; many of them end with a grim acceptance only, as in "Of the Changes of Lyfe" (非76), which ends with the lines "Yixt eftir myd nycht, the myrthfull morrow;/Nixt eftir joy, ay cwmis sorrow:/So is this warld, and ay hes bene" (1.18-20). His optimism, when it does emerge, often is a turning from the world's vanity to a life which involves simple pleasures, as in the refrain from "Of Content" (非72) "He hes anewch that is content." and the last stanza in "Of Cuvetice" (非71): 
Man, pleiss, thy makar and be mirry,

And sett not by this warld a chirry;

Wirk for the place of paradce,

For thairin ringis na covettyce.

The other theme common to many of the moral poems is God's love. Typically this theme is related to earthly love, as in "Of Lufe Erdly and Divine" (\#85), or in the form of a debate, as in "The Merle and the Nychtingale" (非4), in which the two birds present their argument in alternating stanzas. The merle argues for the joys of earthly love while the nightingale argues for the love of God. The argument is won by the nightingale and the last four stanzas end with the nightingale's refrain, emphasizing his victory. The love of God is an important theme in this period but it is used in only two moral poems. As one would expect, it is the primary theme of the sacred poetry.

Six poems form the most obvious connection between the Dunbar of the third perfod and the Dunbar of the second period. These poems, the two vituperatives, "Ballate against Evil Women" (非78) and "Against the Governour" (\#83), and the four laudatory poems "In Praise of Aberdeen" (\#68), "In Prays of Women" (非78), "To the Quene-Dowager" ("\#80), and "Ane Orison, quehen the Gouernour past in France" (非1), display the same style and temperament that many of the second period pieces do. The fact that they occur in this last period indicates that Dunbar's shift to purely moral and sacred considerations was not a complete process.

Dunbar's "Ballate against Evil Women" is a particularly strenuous exercise in vituperative. Written in the rhyme royal stanza used by both Chaucer and King James $I$, it is Dunbar's most caustic castigation. "The Ballate" is followed in the chronology by an apologetic 
poem written in decasyllabic couplets and entitled "In Prays of Woman." 2 After making amends to women, Dunbar ends in a tone appropriately re1igious for this period:

Chryst to his fader he had nocht ane man; Se quhat wirschep wemwm suld haif than. That Sone is Lord, that Sone is King of kingis, In hevin and erth his maiestie ay ringis. 1.30 Sen scho hes borne him in hir halines, And he is well and grund of all gudnes, All wemen of ws suld haif honoring, Serwice and luve, aboif all vthir thing.

The other vituperative poems of this period, "Against the Governour," concerns John, Duke of Albany, who was appointed regent after James IV was killed at Flodden. The poem attacks John for living in France. ${ }^{3}$ Beginning with the ironic line "We Lordis has chosin a chiftane mervellus" (1.1), it describes the deteriorating condition of the kingdom during his absence, a condition emphasized by the refrain "In lak of iustice this realme is schent allace!" After "Against the Governour," he wrote only moral and religious poetry. All of Dunbar's religious verse is attributed to his final period. Fourteen poems fall into this category and of these, eleven are in the ballade stanza of eight refrained lines. Only the poems "A Prayer" (非8), "Hymn for Lent" (非93) and "Ane Ballat of our Lady" (\#97) are not in this form. Also, eleven of the fourteen are hymns, the exceptions being "The Taible of Confessioun" ("k87), "A Prayer" (非8), and "Of the Warldis Vanity" (非101). As might be expected, the hymns tend to be similar in kind and quality with only one or two standing out as exceptional in some way. One hymn that excels the others is the Easter hymn "Done is a battel1. on the dragon blak" (\#96), which presents a long series of images associated with the Easter 
celebration. The hymn is not aureate; and each image is presented in a clear, crisp manner which vivifies it:

Done is a battell on the dragon blak, Our campioun Chryst confoundit hes his force;

The yettis of hell ar brokin with a crak, The signe trivmphall rasit is of the croce, The diuillis trymmillis with hiddouss voce, 1.5 The saulis ar borrowit and to the bliss can go, Chryst with his blud our ransonis dois indoce: Surrexit Dominus de sepulchro.

The rest of the poem proceeds in a similar manner, presenting image upon image, each reiterating the Easter theme. In subsequent stanzas the devil appears as "the deidly dragon." "The crewall serpent," and best of all "The auld kene tegir," while Christ is "a lamb," "a lyone," a "Gyane" and, in an unusual figure for Dunbar, "the glorius Appollo."

The most outstanding of Dunbar's endeavors in religious verse is his hymn to the Virgin, "Ane Ballat of our Lady." This is a religious panegyric, and like his laudatory verse, it is a long list of superlatives. Unlike other poems however, it is a study in extensive internal rhyme:

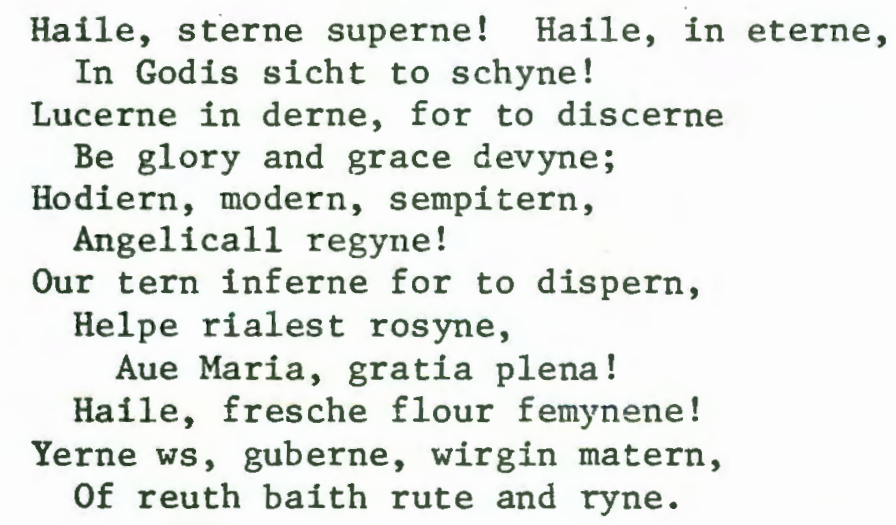

With the triple rhyme in the alternating lines the poem is an excellent example of the poet's virtuosity.

With the exception of the rather formulaic "Taible of Confessioun" ("\#87), only one religious poem retains the poet's personal 
voice. The poem, entitled by Mackay "A Prayer" (非8), is appended to "Ballate against Evil Women" without a title. In one alliterated stanza it profects Dunbar's faith more than any of his other religious poems.

Salviour, suppois my sensualitie

Subject to syn hes maid nyy saull of syss, Sum spark of licht and spiritualitie, Walkins my witt, and ressoun bidis me rys, My corrupt conscience askis, clipis, and cryis First grace, syn space, for to amend my myss, Substance with honour doing nane suppryss, Freindis prosperitie heir, peax, syn heavins blys. 1.49

Because of its personal tone this poem is unique among the religious poems .

A dual process, then, takes place in the third period, for Dunbar completes the refinement of form and theme which began in the second period, while withdrawing the personal volce in deference to the requirements of the hymnal form of his last works. 
${ }^{1}$ Mackay, p. cii.

2This is the third instance in Dunbar's work in which a vituperative or otherwise critical poem is accompanied by an apology. The other two instances are the poem "The Turnament of the Telyour and Sowtaris," which is followed by "The Amedis to the Telyouris and Sowtaris," and the poem "Of James Doig, Kepar of the Quenis Wardrop," which is followed by "Of the same James, quehen he had plesett him."

3

Mackay, p. clxx. 


\section{CHAPTER V}

It is my contention in this paper that while William Dunbar was well acquainted with Chaucer's work, so familiar with it in fact as to carry echoes of Chaucerian phrases even into the latest period of his verse, the development of Dunbar's craft after his initial or apprenticeship period is in an independent direction, and particularly so in respect to his stylistic virtuosity.

Dunbar uses five stanzaic patterns employed by Chaucer: the decasyllabic couplet, septets (rhyme roya1), octaves, the nine-line stanza and the popular "ballade" measure of eight lines with a refrain. Significantly, the nine line stanza occurs in one poem only, "The Goldyn Targe" (非12); decasyllabic couplets occur in only two poems, "The Freiris of Berwik" (非) and "In Prays of Woman" (非78) and octaves are found only in the two poems "The Flyting of Dumbar and Kennedie" (非30) and "A Preyer" (作88). Thus it is that two of Dunbar's poems, "The Freiris," in the fabliau tradition in which Chaucer excelled, and "The Goldyn Targe," in the tradition of The Romance of the Rose, which Chaucer translated, are in metrical forms used by Chaucer. Implicit in this correspondance is the parallel infrequent use of both form and style; as Dunbar moves away from Chaucer's dramatic narrative style he makes a corresponding move away from those forms associated with 1t. Only in the poems "In Prays of Woman" and "A Prayer" does he revert to the decasyllabic couplet and the octave of his early period. One of the two forms that Dunbar retains in his later periods 
is a popular lyric form of the mediaeval period, the ballade. It is the form Chaucer emp-loys in "To Rosemounde," in "Womanly Noblesse" and in "Balades de Visage sanz Peinture." Dunbar uses it in twentysix poems. The other form that he retains in his late verse is the Chaucerian rhyme royal. Dunbar employs it in five poems. Dunbar's use of the French forms employed by Chaucer does not, however, establish influence, for as Denton Fox observes "the Scots poets, Inhabitants of an independent country traditionally allied with France against England, were perfectly capable of going directly to French poetry." 1

In addition to the metrical echoes, Dunbar's poetry contains certain structures, such as the dream vision and the lyric moral poem, which Chaucer also used. Examination of the two poets' use of these structures reveals the superficial likeness and the more substantive differences in their work. Dunbar, even in those poems which seem most Chaucerian, has a distinct poetic voice. For instance, Dunbar employs the dream vision format, which Chaucer uses in "The Romaunt of the Rose," "The House of Fame," and "The Parliament of Fowls," in several of his poems in both the first and second periods. His most Chaucerian use of this format is in "The Goldyn Targe," which has similarities to Chaucer's translation "The Romaunt of the Rose." Both poems are love allegories told as dreams which take place in the "1ocus amoenus" of a garden, but beneath these resemblances are distinct differences in the telling of the tale and in its point. Chaucer's "Romaunt," in octosyllabic couplets, tends towards prolix narrative whereas Dunbar's "Targe" is presented in concise, imagistic nine line stanzas. The differences are apparent if one compares Chaucer's 
description of the May morning:

That it was May me thoughts tho-

It is fyve yer of more ago-

That it was May, thus dremed me,

In tyme of love and jolite,

That al gynneth waxen gay,

For ther is neither busk nor hay

In May, that it nyl shrouded ben,

And it with newe leves wren.

These wodes eek recoveren grene,

That drie in wynter ben to sene;

And the erthe wexith proud withalle,

For swote dewes that on it falle

60

And the pore estat forget

In which the wynter had it set. ${ }^{2}$

with Dunbar's quick establishing of the dream scene, the "locus amoenus"

and the time of year:

Ryght as the stern of day begouth to schyne,

Quhen gone to bed war Vesper and Lucyne,

I raise, and by a rosere did me rest;

Wp sprang the goldyn candill matutyne,

With clere depurit bemes cristallyne,

Glacing the mery foulis in thair nest;

Or Phebus was in purpur cape revest

Wp raise the lark, the hevyns menstrale fyne

In May, in till a morow myrthfullest.

Although both passages are descriptive, Dunbar's version is more

lyrical than Chaucer's, a quality that is due perhaps to Dunbar's

use of alliteration and his longer line. The immediacy of his pre-

sentation is also apparent. Dunbar gets to the heart of his subject,

a characteristic of all of his verse, with a language that is at once

precise and evocative and appropriate to his critical purpose.

Dunbar retains this drean format in several later poems, adapt-

ing it to his lyric verse. The poems "Against Swearing" (非3), a

moral poem, "Ane Ballat of the Fenyeit Frier of Tungland" (非6), a

vituperative poem, and "The Dance of the Sevin Deidly Synnis" ("k33),

a satiric allegory, contain brief dream vision introductions. Each 
poem moves from the seemingly Chaucerian beginning into the concise, personal lyric that is distinctly Dunbar's.

The resemblances between the two poets' moral lyrics are also superficial. Chaucer's three moral lyrics, "Balade de Bon Conseyl," "Gentilesse," and "Lak of Stedfastnesse," are not, despite their label, formal "balades." They do consist of three stanzas and an envoi but they are written in rhyme royal rather than in the required octet of the formal "ballade." Dunbar writes only one of his thenty-one moral lyrics in this measure, the one stanza septet "Of Lyfe" (非100). A comparison of one of Dunbar's moral poems with one of Chaucer's reveals significant differences.

Dunbar's "O Wreche Be War" (非101) and Chaucer's "Balade de Bon Conseyl" deal with the problem of proper conduct in an unstable world. While both poems begin with an admonition to the reader Dunbar's begins with " 0 wreche, be war! this warld will wend the fro" and Chaucer's with "Flee fro the prees, and dwelle with sothfastnesse," it quickly becomes apparent that the poets have distinctly different qualities in their voices. Dunbar's highly alliterated line is more immediate and arresting than is Chaucer's and the exclamation "O wreche" injects a personal tone that Chaucer's less emotional line lacks. These characteristic differences remain true throughout the rest of the poems. Chaucer's first indicates the plain, impersonal language of the poem:

Flee fro the prees, and dwelle with sothfastnesse, Suffyce unto thy good, though it be smal; For hord hath hate, and climbing tikelnesse, Prees hath envye, and wele blent overal; Savour no more than thee bihove shal;

Reule wel thyself, that other folk canst rede; And trouthe thee shal delivere, it is no drede. 
His words have a sermonizing quality created by the use of the slightly elevated words "Suff-yce" and "Savour." Dunbar's first stanza contrasts with Chaucer's sermonizing:

0 wreche, be war! this warld will wend the fro, Quhilk hes begylit mony greit estait;

Turne to thy freynd, belief nocht in thy fo, Sen thow mon go, be grathing to thy gait;

Remeid in tyme, and rew nocht all to lait;

Provyde thy place, for thow away man pass

Out of this vaill of trubbill and dissait:

Vanitas Vanitatum, et omnia Vanitas.

Beneath Dunbar's homey advice to "Turne to thy freynd, belief nocht In thy fo" lies a secondary meaning which adds a depth to his poem, a depth lacking in Chaucer's. On the surface level Dunbar is offering the practical advice that one should rely upon one's friends, but on a different level he is making an equation between the friend and Christ and between the foe and Satan. Thus he is not only offering practical temporal advice but sound spiritual advice as we1l. This interpretation is supported in the sixth line, "Provyde thy place, for thow away man pass," which may mean either that one should provide for his practical needs or that one should provide his place in heaven now, since one must eventually die. Underscoring the secondary interpretation of both lines is the refrain line "Vanitas Vanitatum, et omnia Vanitas."

Chaucer's second stanza continues with the same sermonizing tone as in the first but his third stanza varies from the first two and provides an interesting comparison with Dunbar's second stanza, to which it is similar:

That thee is sent, receyve in buxumnesse; The wrastling for this world axeth a fal. Her is non hoom, her nis but wildernesse; Forth, pilgrim, forth! Forth, beste, out of thy sta1! 
Know thy contree, 100 up, thank God of al;

Hold the heye wey, and lat thy gost thee lede;

And trouthe thee shal delivere, it is no drede.

As in Dunbar's poem these lines offer more than one interpretation. The first line above, "That thee is sent, receyve in buxumnesse," means either that one is to receive humbly whatever one is given, in the temporal sense, or spiritually that one should humbly receive the gift of God's grace. Similarly, the line beginning "Hold the heye wey" suggests either practical travelling advice in the sense of staying on the high road or spiritual advice in the sense of keeping one's mind on heaven. These interpretations are made obvious by the Biblically suggestive exclamation "Forth, pilgrim, forth!" which adds a new vitality to Chaucer's heretofore unemotional poem. This exclamation is echoed in Dunbar's second stanza:

Wakk furth, pilgrame, quhill thow hes dayis lycht, Dress fro desert, draw to thy dwelling-place; Speid home, for-quhy anone cummis the nicht Quhilk dois the follow with ane ythand chaise! Bend up thy saill, and win thy port of grace; For and the deith ourtak the in trespas, Then may, thow say thi.r worais with allace! Vanitas Vanitatum, et omnia Vanitas.

Dunbar's command to the pilgrim is less exuberant than Chaucer's but his stanza is nonetheless made vibrant through the use of the descriptive verbs "Dress "Speid and "Bend As in his first stanza, his lines are ambivalent but here that ambivalence is made more obvious through the image of the pilgrim, who is told to hurry home while he has 1ight, which also means that he should gain heaven while he has 1ife. Death is symbolized by the word "nicht" in this stanza and Dunbar's description of "the nicht/Quhilk dois the follow with ane ythand chaise" is a "tour de force" in combining the night/death 
image with the image of the foe from the first stanza.

Chaucer's envoy, a septet rather than the usual quatrain, concludes his poem by relinquishing the moral tone of the poem and supplanting it with direct religious references:

Therfore, thou Vache, leve thyn old wrecchednesse; Unto the world leve now to be thral; Crye him mercy, that of his hy goodnesse

Made thee of noght, and in especial

Draw unto him, and pray in general

For thee, and eek for other, hevenlich mede;

And trouthe thee shal delivere, it is no drede.

By changing to an explicitly religious tone Chaucer reemphasizes the sermon quality of his first two stanzas; he steps back from the fam1liarity of his third stanza and consequently diminishes that tone in favor of the impersonal stance. Dunbar, on the other hand, does not step out of the strictly moral vein:

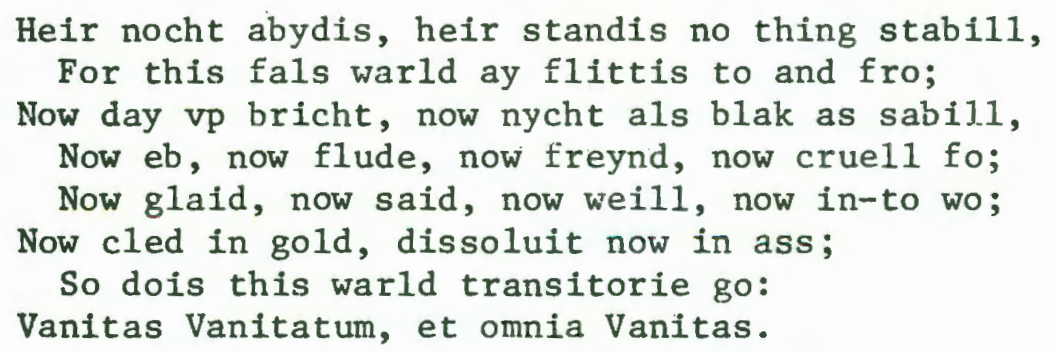

This final metric and verbal flurry emphasizes the world's mutability and the consequent necessity of accepting the advice given in the preceding portion of the poem. Dunbar drives home his point that "this warld will wend the fro" with an inclusive catalogue of the world's various conditions and the simple final statement "So dois this warld transitorie go." Because he remains committed to the moral vein of his poem in this last stanza, his poem avoids the sermonizing effect of Chaucer's work and his ambiguous lines retain their tantalizing ambiguity. 
Although echoes of Chaucer's "Balade de Bon Conseyl" are evident in Dunbar's "O Wreche be War," it is apparent in this comparison that Dunbar's poetic voice is distinctly his own. His energetic treatment of his subject avoids Chaucer's didacticism by employing simple, concise images. By means of alliteration, flexible metric pattern, and simple diction, he creates a lyric that is at once personal and universal.

Thus far I have dealt with those areas in Dunbar's poetry which seem to reflect Chaucer's influence. In each instance Chaucer's influence has been shown to be superficial. There are, however, several poems which are distinctly Dunbar, showing no trace of Chaucer's influence. These are the best examples of the voice of the Scottish "makar".

In the Dunbar canon four poems stand out as particularly personal 1yrics, "To a Ladye" (非0), "Meditatioun in Wyntir" (非5), "My heid did yak yesternicht" (非2) and "To the King, The Petitioun of the Gray Horse, Auld Dunbar" (非59). Arther Moore in The Secular Lyric in Middle English notes that this personal verse is unprecedented when he says "In truth, Dunbar's literary background was singularly deficient in the type of poetry which he was by temperament best qualified to manage. ${ }^{3}$ Although these four poems are frequently anthologized, they have received little critical attention, which is unfortunate. Certainly, attention to these poems provides the most positive rebuttal to the title "Scottish Chaucerian." Since each of the four displays all of the characteristics which distinguish Dunbar's verse, I will deal with only one of them.

"The Petitioun of the Gray Horse, Auld Dunbar," written in sextets 
rhymed aaabbb, revolves around the extended metaphor that Dunbar is an old horse and that he wishes to have new trappings so that he might not be called "ane Yuilis yald." This metaphor serves as a thin disguise to Dunbar's rather bitter cry that he has given his life to the King's service and has received little in compensation. Intermediary to these two interpretations is the possibility that Dunbar's metaphor is simply a thinly disguised begging poem in which Dunbar is asking the King to give him new clothes for the Christmastide. Whether one interprets the poem on the first, the second, or the third level, the most important aspect of the poem remains: "The Petitioun" is a personal poem. Dunbar sets the scene of his poem by asking, in the first stanza, a. question that a horse might ask himself at Christmas:

$$
\begin{aligned}
& \text { Now Lufferis cummis with largess lowd, } \\
& \text { Quhy sould not palfrayis thane be prowd, } \\
& \text { Quhen gillettis wilbe schomd and schroud, } \\
& \text { That ridden ar baith with lord and lawd? } \\
& \text { Schir, lettit nevir in toun be tald } \\
& \text { That I sould be ane Yuilis yald! }
\end{aligned}
$$

This sets his scene and tone(s) immediately by giving the reader the information that the question seems to be coming from a "Palfray" and that in the last two lines he is addressing his master, asking him to save him (the horse) from the mocking title "Yuilis yald." These last two lines are slightly ambiguous, however, and they may be interpreted to mean "don't let it be gossiped around town that you have allowed me to become 'ane Yuills yald'."

The next two stanzas contrast the horse's happy youth with his miserable present:

Quhen I was young and into ply, And wald cast gammaldis to the sky, I had beine bocht in realmes by, Had I consentit to be sald. 
Schir, lett it nevir in toun be tald, That I sould be ane Yuilis yald.

With gentill horss quehen I wald knyp, Thane is thair laid on me any quhip, To colleveris than man I skip,

That scabbit ar, hes cruik and cald.

Schir, lett it nevir in toun be tald,

That I sould be ane Yuilis yald.

Dunbar makes the contrast between the past and present through the use of different language levels. The words "gammaldis" and "realmes" in the second stanza summon up happy, positive, youthful emotions while the words "scabbit", "cruik" and "cald" emphasize the unhappy present with rough, abrupt sounds. In these two stanzas the poem becomes especially more personal by dint of the constant repetition of the first person pronoun; he uses the word "I" seven times in the secand and third stanzas. This constant repetition enforces an intense personification of the horse; indeed, the personification is so forced that Dunbar risks dissolving his metaphor altogether. That he does not disrupt his metaphor is, perhaps, the finest point in the poen. Although he pushes the metaphor to its limits, Dunbar remains committed to it. He remains horse and poet equally throughout the work and it is the tension between the two levels of meaning which gives the poem its emotional and intellectual complexity.

In the fifth and sixth stanzas Dunbar pushes his metaphor first from the side of the man and then from the horse's side:

Suppois I war ane ald yaid aver, Schott furth our clewch to pull the clever,

And had the strenthis off all Strenever,

I wald at Youll be housit and stald, Schir, lett it nevir in toun be tald, That I suld be ane Yuillis yald!

I am ane auld horss, as ye knaw

That evir in duill dois drug and draw; 
Great court horss puttis me fra the staw,

To fang the fog be firthe and fald.

Schir, lett it nevir in toun be tald,

That I suid be ane Yuilis yald!

In the fifth stanza the poet says in effect "Suppose I was a horse, I would at least be clothed and fed at Christmas." In the sixth stanza the horse says that he is an old horse and yet that Court horses have taken his just dues. In making the contrasting statements Dunbar maintains the metaphoric tension of the poem yet manages to emphasize his point from both positions of the metaphor. By this time, the comic effect of the metaphor has given way to a more caustic tone through the succession of such grim images as the whip and horse diseases ("scabbit," "cruik," and "cald") of the third stanza and the work image ("in duill dois drug and draw") of the sixth. These grim images are followed by others in the next three stanzas which describe the horse/poet:

I haif run lang furth in the feild, On pastouris that ar plane and peild;

I mycht be now tein in for eild, My beikis ar spruning he and bauld.

Schir, lett it nevir in toun be tald, That I sould be ane Yuilis yald!

My mane is turned in to quhyt, And thairof ye haff all the wyt!

Quhen uther horss had bran to. byt

I gat bot griss, cnype gif I wald Schir, lett it nevir in toun be tald, That I sould be ane Yuilis yald

I was nevir dautit into stabell, My lyf hes bene so miserabie, My hyd to offer I am abill,

For evill schom strae that I reive wald.

Schir, lett in nevir in toun be tald, That I sould be ane Yuilis yald.

The language that the horse uses to describe his physical condition is of a low level and thus when he says, "My beikis ar spruning he and 
bauld," the image of his corner teeth jutting out from his mouth is all the more real because of its harsh, colloquial expression. As Dumbar's caustic tone becomes more apparent -- indeed, in line forty-four he directly accuses his master (the King) in the line "And thairof ye half all the wyt!"-- his alliteration increases, which gives his language a speclal bite. In the ninth stanza he complains that his life is so miserable that he is willing to exchange skin for some poor straw to eat. This image is picked up in the next stanza in the most grotesque image of the poem:

And yitt, suppois my thrift be thyne, Gif that I die your aucht within, Latt nevir the soutteris have my skin, With uglie gumes to be gnawin. Schir, lett it nevir in toun be tald, That I sould be ane Yuilis yald.

With this image, Dunbar culminates his castigation and subsides into a rather meek tone in the last stanza:

The court hes done my curage cuill, And maid the ane forriddin muill; Yett, to weir trappouris at this Yuill, I wald be spurrit at everie spald. Schir, lett it nevir in toun be tald, That I sould be ane Yuilis yald.

This stanza returns to the petition for trappings for the Christmas celebrations, which was the ostensible motive for the poem, renewing that petition and leaving a final image of a broken but still obedient servant placing a humble request.

The metaphoric and linguistic complexity of "The Petitloun" is a striking example of those qualities which distinguish Dunbar's poetic voice from that of any other poet. It reveals his ability to evoke differing emotional tones through the versatile selection of language levels, poetic devices, and imagery. Moreover, it 
shows the razor-sharp edge that his lyrics could achieve through the active use of the various levels of Middle Scots and his own metric versatilty. Highly personal, "The Petitioun" prefigures the more self-conscious Renaissance and demonstrates that Duntar does not rely upon echoing Chaucer for poetic greatness. Those qualities which are uniquely his own establish the originality and integrity of his work and distinguish him not as a Scottish Caucerian but as an outstanding Scots "makar." 
FOOTNOTES TO CHAPTER $v$

1Denton Fox, "The Scottish Chaucerians," in Chaucer and Chaucerians, ed. D. S. Brewer (University of Alabama: University of Alabama Press, 1966), pp. 164-201.

2 All Chaucer quotations are from F. N. Robinsons, ed., The Works of Geoffrey Chaucer (Boston: Houghton Mifflin, 1957).

${ }^{3}$ Arthur K. Moore, The Secular Lyric in Middle English (Lexington: University of Kentucky Press, 1951), p. 197. 


\section{A SELECTED BIBLIOGRAPHY}

Baxter, J.W. William Dunbar: A Blographical Study. St. Clair Shores: Scholarly Press, 1971.

A Choice of Scottish Verse 1470-1570, ed. John and Winifred MacQueen. London: Faber and Faber, 1972.

Dickinson, William Croft. A New History of Scotland, vol. 1. London: Thomas Nelson and Sons, 1961.

Dunbar, William. The Poems of William Dunbar, ed. John Sma11. Edinburgh: William Blackwood and Sons, 1893.

Dunbar, William. The Poems of William Dunbar, ed. W. Mackay MacKenzie. London: Faber and Faber, 1932.

Dunbar, William. Poems, ed. James Kinsley. Oxford: Clarendon Press, 1958.

Ebin, Lois A. "The Theme of Poetry in Dunbar's 'Goldyn Targe"." The Chaucer Review, 7, No. 2 (1972), 147-159.

Eddy, E1izabeth Roth. "Sir Thopas and Sir Thomas Norny: Romance Parody in Chaucer and Dunbar." Review of English Studies, 22, No. 88 (1971), 401-409.

Fox, Denton. "The Scottish Chaucerians." Chaucer and Chaucerians. Ed. D.S. Brewer. University of Alabama: University of Alabama Press, 1966.

Irving, David. The History of Scottish Poetry, ed. John Aitken Carlyle. Ist ed., 1861; rpt. New York: Johnson Reprint Corp. 1972.

Jack, Ronald D.S. Review of Dunbar: A Critical Exposition of the Poems by Tom Scott. Scottish Studies, vol. II, 1967, 113-115.

Kinghorn, A.M. "Dunbar and Villon - A Comparison and a Contrast," Modern Language Review, 62, No. 2 (1967), 195-208.

Kinghorn, A.M. The Middle Scots Poets. London: Edward Arnold, 1970.

Lewis, C.S. English Literature in the Sixteenth Century. Oxford: Oxford University Press, 1954.

Mackenzie, W. Mackay. The Poems of William Dunbar. London: Faber and Faber, 1932. 
Mediaeval Scottish Poetry, ed. George Eyre-Todd. Ist ed., 1892; rpt. Westport, Connecticut: Greenwood Press, 1971.

Moore, Arthur K. The Secular Lyric in Middle English. Lexington: University of Kentucky Press, 1951.

Morgan, Edwin. Review of William Dunbar: Poems, ed. James Kinsley. Review of English Studies, 11, No. 41 (1960), 71-73.

Religious Lyrics of the XVth Century, ed. Carleton Brown. 1st ed., 1939; rpt. Oxford: Clarendon Press, 1967.

Rigg, A.G. "William Dunbar: The 'Fenyeit Freir'," Review of English Studies, 19, No. 55 (1963), 269-273.

Secular Lyrics of the XIVth and XVth Centuries, ed. Russell Hope Robbins. Ist ed., 1952; rpt. Oxford: Clarendon Press, 1968.

Spitzer, Leo. "Explication de texte' Applied to Three Great Middle English Poems." Essays on English and American Literature. Ed. Anna Hatcher. Princeton: Princeton University Press, 1968, pp. 193-247.

Wittig, Kurt. The Scottish Tradition in Literature. Edinburgh: Oliver and Boyd, 1958.

Wood, Clement. Poèt's Handbook. Cleveland: World Publishing Company, 1946.

Wood, Harvey. Two Scots Chaucerians. London: Longmans, Green, 1967.

The Works of Geoffrey Chaucer, ed. F.N. Robinson. 2nd ed., Boston: Houghton Mifflin. 
APPENDIY A

CHRONOLOGICAL CHART OF THEMES AND FOPMS

\begin{tabular}{|c|c|c|c|}
\hline No. & Title & Theme & Form \\
\hline 1 & A New Year's Gift to the King & prec & $4 \mathrm{w}$ \\
\hline 2 & The Tod and the Lamb & hum & $7 \mathrm{w}$ \\
\hline 3 & Ane Brash of Wowing & hum & $7 \mathrm{w}$ \\
\hline 4 & The Dregy Maid to the Kyng & hum & $\mathrm{sc} / \mathrm{tr} \mathbf{1}$ \\
\hline 5 & Aganis the Solistaris in Court & vit & sc \\
\hline 6 & The Tua Mariit Wemwn and the Wedo & narr & allit \\
\hline 7 & The Twa Cummeris & hum & 5w \\
\hline 8 & The Freiris of Berwik & narr & 1c \\
\hline 9 & The Ballad of Kynd Kittok & hum & 5w \\
\hline 10 & Learning vain withoug quid Lyfe & moral & $8 w$ \\
\hline 11. & In Praise of London & laud. & $8 w$ \\
\hline 12 & The Goldyn Targe & alleg & $9 w / 0$ \\
\hline 13 & Beauty and the Prisoner & alleg & $8 w$ \\
\hline 14 & The Thistle and the Rose & alleg & $7 w / 0$ \\
\hline 15 & $\begin{array}{l}\text { Welccme of Margaret as Queen of } \\
\text { Scotland }\end{array}$ & laud & $4 \mathrm{w}$ \\
\hline 16 & $\begin{array}{l}\text { Ane Iittil Interlud of the } \\
\text { Droichis part of the Play }\end{array}$ & alleg & tail \\
\hline 17 & To the Queen & laud & $8 w$ \\
\hline 18 & Against Treason & vit & wheel \\
\hline 19 & Tidings from the Session & vit & $7 w$ \\
\hline 20 & Lady Solistaris at Court & sat & ta11 \\
\hline 21 & Aganis the Solistaris in Court & vit & sc \\
\hline 22 & Satire on Edinburgh & vit & wheel \\
\hline 23 & Against Swearing & moral & $5 w$ \\
\hline 24 & To the Quene & moral & $5 w$ \\
\hline 25 & Of a Dance in the Quenis Chalmer. & sat & $7 w$ \\
\hline 26 & $\begin{array}{l}\text { Ane Ballat of the Fenyeit Freir } \\
\text { of Tungland }\end{array}$ & vit & tail \\
\hline 27 & The Birth of Antichrist & vit & $5 w / 0$ \\
\hline 28 & The Dream & vit & $5 w / 0$ \\
\hline 29 & $\begin{array}{l}\text { How Dumbar wes desyrd to be ane } \\
\text { Kenned:e }\end{array}$ & vit & $5 w / 0$ \\
\hline 30 & $\begin{array}{l}\text { The rlyting of Dunbar and } \\
\text { Kennedie }\end{array}$ & vit & $8 w / 0$ \\
\hline 31 & Lament for the Makaris & moral & $4 / w$ \\
\hline 32 & My heid did yak yesternicht & moral & $5 w / 0$ \\
\hline 33 & $\begin{array}{l}\text { The Dance of the Sevin Deidly } \\
\text { Synis }\end{array}$ & sat & $\operatorname{ta11}$ \\
\hline 34 & The Turnament of the Telyour and & vit & tail \\
\hline
\end{tabular}


No.

35

36 The Testament of Mr. Andro Kennedy
37 Of Ane Blak-Moir

38 The Ballau of Lord Bernard Stewart

39 Elegy on the Death of Bernard Stewart

40 To a Ladye

41 Beye ane Luvar, think ye nocht ye suld

42 Fane wald I Luve, bot quhair abowt?

43 Gif ye wald Lufe and Luvit be

44 To a Ladye

45 Quha will behald of Luve the chance

46 of James Doig, Kepar of the Quenis Wardrop

47 of the same James, quhen he had plesett him

48 of Sir Thomas Norray

49 Complaint against Mure

50 Faine wald I, with all diligence

51 To the King, on his Empty Purse

52 To the king, that he war Johne Thomosunis Man

53 To the King, quhen mony Benefices vakit

54 To the King, after the Benefices were filled up

55 To the King, rècalling his Services

56 To the King, of the Worldis Instabilitie

57 To the King, Dunbar's Complaint

58 To the King, Dunbar's Remonstrance

59 To the King, The Petition of the Gray Horse, Auld Dunbar

60 of Discretioun in Asking

61 of Discretioun in Giving

62 of Discretioun in Taking

63 Welcome to the Lord Treasurer

64 To the Lords Exchequer

65 Every one his own Enemy

66 Full oft I muss and hes in thocht

67 Hermes the Philosopher

68 In praise of Aberdeen

69 How sowld I rewill me, or quhat wyiss

70 of Deming

71 of Covetis

72 of Conten:

73 Man, sen thy Lyfe is ay in Weir

74 Rule of One's Self

75 Meditatioun in Wyntir

76 of the Changes Lyfe

77 Vallate against Evil Women

78 In Prays of Woman

79 Doun by ane Rever as I red
Theme

laud

hum

hum

laud

laud

love

love

love

love

Iove

moral

vit

laud

sat

vit

love

prec

prec

prec

prec

prec

prec

prec

prec

prec

prec

prec

prec

laud

prec

moral

moral

moral

laud

moral

moral

moral

mora1

moral

moral

moral

moral

vit

laud

moral
Form

4พ

$8 w / 0 / 4$

$5 \mathrm{~W}$

8 w

$8 w$

$5 w / 0$

$8 w$

$5 w$

4w

$7 w / 0$

ta11

4w

4w

tail

$7 \mathrm{w}$

$5 w$

$5 w$

4w

$5 w / 0$

$5 w$

$5 w$

4W

sc

$\mathrm{SC}$

$6 \mathrm{w}$

$5 w$

$5 w$

$5 w$

$4 \mathrm{w}$

$5 w / 0$

$5 \mathrm{w}$

$5 w$

$8 w$

$8 w$

$5 w$

$5 w$

4w

5w

4W

$8 w$

$5 w / 0$

$5 \mathrm{w} / 0$

$7 w / 0$

1c

$8 w$ 
No.

Title

80 To the Quene-Dowager

81 Ane Orisoun, quhen the Gouernour past. in France

82 Quhome to sall I complene my woo

83 Against the Governour

84 The Merle and the Nychtingale

85 Of Lufe Erdly and Divine

86 All Erdly Joy returns in Pane

87 The Taible of Confessioun

88 A Prayer

89 Rorate celi desuper

90 Jerusalem reioss for joy

91 Now glaidith euery liffis creature

92 The Sterne is rissin of our redemption

93 O synfull man, thir ar the fourty dayis

94 The Passioun of Christ

95 The Resurrection of Christ

96 Done is a battell on the dragon blak

97 Ane Ballat of our Lady

98 Roiss Mary most of vertew virginall

99. Of Man's Mortalitie

100 of Lyfe

101 of the Warldis Vanity

\begin{tabular}{ll} 
Theme & Form \\
\cline { 2 - 2 } maud & $8 \mathrm{w}$ \\
laud & $8 \mathrm{w}$ \\
moral & $5 \mathrm{w}$ \\
vit & $8 \mathrm{w}$ \\
mora1 & $8 \mathrm{w}$ \\
moral & $6 \mathrm{w}$ \\
moral & $4 \mathrm{w}$ \\
rel & $8 \mathrm{w}$ \\
re1 & $8 \mathrm{w} / \mathrm{c}$ \\
rel & $8 \mathrm{w}$ \\
rel & $8 \mathrm{w}$ \\
rel & $8 \mathrm{w}$ \\
rel & $8 \mathrm{w}$ \\
rel & $7 \mathrm{w} / 0$ \\
rel & $8 \mathrm{w}$ \\
re1 & $8 \mathrm{w}$ \\
rel & $8 \mathrm{w}$ \\
rel & $w h e e 1$ \\
rel & $8 \mathrm{w}$ \\
rel & $8 \mathrm{w}$ \\
moral & $7 \mathrm{w} / 0$ \\
rel & $8 \mathrm{w}$
\end{tabular}

* Abbreviations are as follows:

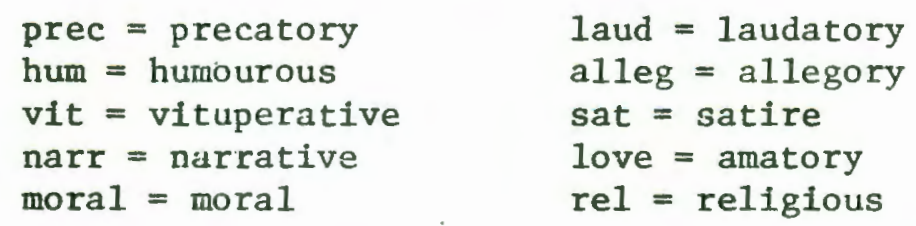

+ Numbers designate the number of lines per stanza. Abbreviations for letters are as follows:

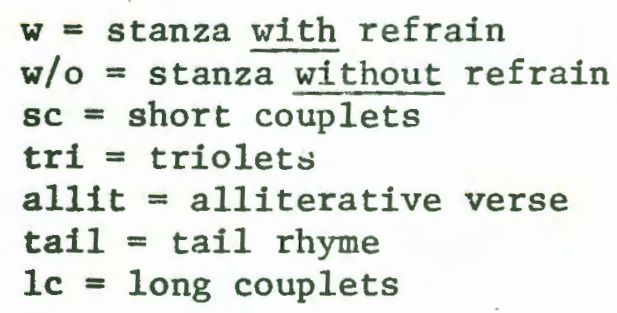


APPENDIX B

SELECTED POEMS

"A New Year's Gift to the King" (\#1)

My prince in God gif the guid grace, Joy, glaidnes, confort, and solace, Play, pleasance, myrth, and mirrie cheir, In hansell of this guid new yeir.

God gif to the ane blissed chance,

And of all vertew aboundance, And grace ay for to perseveir,

In hansell of this guid new yeir.

God giue the guid prospertie,

Fair fortoun and felicitie,

Euir mair in earth quhill thow ar heir,

In hanse11 of this guid new yeir.

The heavinlie Lord his help the send, Thy realine to reuli and to defend, In peace and justice it to steir, In hansell of this guid new yeir.

God gif the blis quhair euir thow bownes, And send the many Fraunce crownes, Hie liberal1 heart, and handis nocht sweir, In hansell of this guid new yeir.

Quod Dumbar 
"Learning vain without guid Lyfe" (非10)

To speik of science, craft, or sapience, off vertew, morall cwnnyng, or doctrine;

off jure, of wisdome, or intelligence;

off eurerie study, lair, or discipline;

Al1 is bot tynt, or reddie for to tyne,

Nocht vsing it as it sould vsit be;

The craift exerceing, considdering not the fyne:

Ane paralous seiknes is vaine prosperite.

The curious probatioun logicall:

The eloquence of ornat rethorie;

The naturall science philosophical1;

The dirk apperance of astronomie;

The theologis sermoun; the fablis of poetry;

Without gud lyfe all in the self dois de,

As Mayis flouris dois in September dry:

A paralous lyfe is vaine prosperite.

Quhairfoir, ye clarkis grittest of constance; Fullest of science and of knawlegeing,

To ws be myrrouris in your governance;

And in our darkness be lampis in schyning:

Or than in frustar is all your lang leirning;

Gif to your sawis your deidis contrair be, Your maist accusar salbe your awin cwnning:

A peralus seikness in vane prosperitie.

Quod Dumbar at Oxinfurde 
"Of a Dance in the Quenis Chalmer" (非25)

Schir Jhon Sinclair begowthe to dance,

For he was new cum owt of France;

For ony thing that he do mycht,

The ane futt yeid ay onrycht,

And to the tother wald not gree.

Quoth ane, "Tak vp the Quenis knycht:"

A mirrear Dance mycht na man see.

Than came in Maister Robert Scha:

He leuket as he culd lern tham a;

Bot ay his ane futt did wawer,

He stackerit 1yk ane strummal1 awer,

That hap schackellit war abone the kne:

To seik fra Sterling to Stranawer,

A mirrear Daunce mycht na man see.

Than cam in the Maister Almaser,

Ane hommilty jonmeltye juffler,

Lyk a stirk stackarand in the ry;

His hippis gaff mony hiddouss cry.

John Bute the Fule said, "Wa es me!

He is bedirtin,-Fy! fy!"

A mirrear Dance mycht na man se.

Than cam in Dunbar the Mackar;

On all the flwre thair was nane frackar, And thair he daunset the dirrye dantoun; He hoppet lyk a pillie wantoun,

For luff of Mwsgraeffe, men tellis me;

He trippet, quhill he tint his pantoun:

A mirrear Dance mycht na man se.

Than cam in Maestriss Mwsgraeffe;

Scho mycht hef lernit all the laeffe;

Quhen I saw hir sa trimlye dance,

Hir guid conwoy and countenance,

Than, for hir saek I wissitt to be .

The trytast erle, or duik, in France:

A mirrear Dance mycht na man see.

Than cam in Dame Dountebout;

God waitt gif that scho loukit sour!

Scho maid sic morgeownis with hir hippis,

For lauchter nain mycht hald thair lippis;

Quhen scho was danceand bysselye,

Ane blast of wind soun fra hir slippis:

A mirrear Dance mycht na man see. 
Quhen thair was cum in fywe or sax,

The quenis Dog begowthe to rax;

And of his band he maid a bred,

And to the danceing soun he hin maid;

Quhou mastew-lyk a tyk, sum said:

A mirrear jance mycht na man se.

Quod Dumbar of a dance in the

Quenis chalmer 
"Devorit with dreme, devysing in my slumer"

Devorit with dreme, devysing in my slummer, How that this realme, with nobillis owt of nummer, Gydit, provydit sa mony yeiris hes bene;

And now sic hunger, sic cowartis, and sic cummer

Within this land was nevir hard nor sene.

Sic pryd with prellattis, so few till preiche and pray;

Sic aant of harlettis with thame bayth nicht and day, That sowld haif ay thaix God afoir thair ene;

So nyce array, so strange thair abbay, Within this land was nevir hard nor sene.

So mony preistis cled vp in secular weid, With blasing breistis casting thair clsthis on breid, It is no neid to tell of quhome I mene;

So quhene the Psalme and Testament to reid Within this land was nevir hard nor sene.

So mony maisteris, so mony guckit clerkis, So mony westaris to God and all his warkis, So fyry sparkis, of dispyt fro the splene, So losing sarkis, so mony glengoir markis Within this land was nevir hard nor sene.

Sa mony lordis, so mony naturall fulis, That better accordis to play thame at the trulis, Nor seiss the dulis that commonis dois sustene;

New tane fra sculis, sa mony anis and mvlis W1 thin this land was nevir hard nor sene.

Sa mekle tressone, sa mony partiall sawis, Sa litt11 ressone to help the commoun cawis, That all the lawia ar not sett by ane bene; Sic fenyeit flawis, sa mony waistit wawis Within this land was nevir hard nor sene.

Sa mony theivis and mvrdereris weil1'kend, Sa grit relevis of lordis thame to defend, Becawis the spend the pelf thame betwene; So few till wend this mischief till amend, Within this land was nevir hard nor sene.

This to corre:t, thay schoir with mony crakkis, Bot littil effect of speir or battar ax, Quhen curage lakkis the corss that sowld mak kene; Sa mony jakkis, and brattis on beggaris bakkis, Within this land was nevir hard nor sene. 
Sic vant of wostouris with hairtis in sinfull staturis,

Sic brallaris and bosteris, degenerat fra thair naturis,

And sic regratouris, the peure men to prevene;

Sa mony tratouris, sa mony rubeatouris,

Within this land was nevir hard nor sene.

Sa mony jugeis and lordis now maid of lait,

Sa smal1 refugeis the peur man to debait,

Sa mony estait, for commoun weill sa quhene;

Ouir all the gait sa mony thevis sa tait

Within this land was nevir hard nor sene.

Sa mony ane sentence retreitit, for to win

Geir and acquentance, or kyndnes of thair kin,

They think no sin, quhair proffeit cumis betwene;

Sa mony ane gin to haist thame to the pin,

Within this land was nevir hard nor sene.

Sic knavis and crakkaris to play at cartis and dyce, Sic halland schekkaris, quhilk at Cowkelbyis gryce

Ar haldin of pryce, quhen lymmaris lois convene;

Sic stoir of vyce, sa mony wittis vnwyce

Within this land was nevir hard nor sene.

Sa mony merchandis, sa mony as mensworne,

Sa peur tennandis, sic cursing evin and morne, Quhilk slayis the corne and fruct that growis grene;

Sic skaith and scorne, so mony paitlattis worne

Within this land was nevir hard nor sene.

Sa mony rakkettis, sa mony ketche-pillaris, Sic ballis, sic nackettis, and sic tutivillaris, And sic evill-willaris to speik of king and quene;

Sic pudding-fillaris, discending down frome millaris, Within this land was nevir hard nor sene.

Sic fartingailis on flaggis als fatt as quhailis, Facit 1yk fulis with hattis that littil availlis, And sic fowill tailis, to sweip the calsay clene, The dust vpskaillis; so mony fillok with fuck sailis Within this land was nevir hard nor sene.

Sa mony Kittie, drest vp with goldin chenye, So few witty, that weill can fabillis fenye, With apill renye ay schawand hir goldin chene; off Sathanis senyie syne sic ane vnsall menyie Within this land was nevir hard nor sene.

Finis quod Dumbar. 
"Lament for the Makaris" (非31)

I that in heill wes and glaidnes, Am trublit now with gret seiknes, And feblit with infirmitie;

Timor Murtis conturbat me.

Our plesance heir is all vane glory,

This fals warld is bot transitory,

The flesche is brukle, the Fend is sle;

Timor Mortis conturbat me.

The stait of man dois change et vary,

Now sound, now seik, now blyth, now sary,

Now dansand mirry, now like to dee

Timor Mortis conturbat me.

No stait in erd heir standis sickir;

As withe wynd wavis the wickir,

So wavis this warldis vanite;

Timor Mortis conturbat me.

Onto the ded gois all Estaitis, Princis, Prelotis, and Potestatis, Baith riche et pur af all degre; Timor Mortis conturbat me.

He takis the knychtis in to feild, Anarmit vnder helme et scheild;

Wictour he is at all melle;

Timor Mortis conturbat me.

That strang vnmercifull tyrand

Takis on the moderis breist sowkand

The bab, full of benignite;

Timor Mortis conturbat me.

He takis the campion in the stour,

The capitane closit in the tour,

The lady in bour full of bewte;

Timor Mortis conturbat me.

He spairis no lord for his piscence,

Na clerk for his intelligence;

His awfull strak may no man fle;

Timor Mortis conturbat me.

Art, magicians, and astrologgis, Rethoris, logicians, et theologgis, Thame helpis no conclusionis sle;

IImor Mortis conturbat me. 
In medicyne the nost practicianis, Lechis, surrigianis, et phisicianis, Thame self fra ded may not supple;

Timor Mortis conturbat me.

I see that makaris amang the laif

Playis heir ther pageant, syne gois to graif;

Sparitis nocht ther faculte;

Timor Mortis conturbat me.

He hes done petuously devour,

The noble Chaucer, of makaris flouit,

The Mork of Bery, and Gower, all thre;

Timor Mortis conturbat me.

The gude Syr Hew of Eglintoun,

Et eik, Heryot, et Wyntoun,

He hes tane out of the cuntre;

Timor Mortis conturbat me.

That scorpion fell hes done infek

Maister Iohne Clerk, and James Afflek,

Fra balat making et trigide;

Timor Mortis conturbat me.

Holland et Barbour he has berevit;

Allace! that he nought with ws lewit

Schir. Mungo Lokert of the Le;

Timor Mortis conturbat me.

Clerk of Tranent eik he has tane,

That maid the anteris of Gawane;

Schir Gilbert Hay endit has he;

Timor Mortis contrubat me.

He has Blind Hary, et Sandy traill

Slaine with his schour of mortall haill,

Quhilk Patrik Iohnestoun nyght nought fle;

Timor Mortis conturbat me.

He hes reft Merseir his endite,

That did in luf so lifly write,

So schort, so quyk, of sentence hie;

Timor Mortis conturbat me.

He hes tane Roul1 of Aberdeire,

And gentill Roull of Corstorphine;

Two betrir fallowis did no man se;

Timor Mortis conturbat me. 
In Dumfermelyne he has done rovne

With Maister Robert Henrisoun;

Schir Iohne the Ros enbrast hes he;

Timor Mortis conturbat me.

And he has now tane, last of aw,

Gud gent111 Stobo et Quintyne Schaw,

of quham all wichtis hes pete:

Timor Mortis conturbat me.

Gud Maister Walter Kennedy,

In poynt of dede lyis veraly,

Gret reuth it wer that so suld be;

Timor Mortis conturbat me.

Sen he has all my brether tane,

He will naught lat me lif alane,

On forse I man his nyxt pray be;

Timor Mortis conturbat me.

Sen for the deid remeid is non,

Best is that we for dede dispone.

Eftir our died that lif may we;

Timor Mortis conturbat me.

Quod Dunbar quhen he wes seik, etc. 
"The Dance of the Sevin Deidly Synnis"

Off Februar the fyiftene nycht,

Ful1 lang befoir the dayis lycht, I lay in till a trance;

And then I saw baith hevin and he11:

Me thocht, amangis the feyndis fell,

Mahoun gart cry ane dance

off schrewis that wer nevir schrevin, Aganiss the feist of Fasternis evin,

To mak thair observance;

He bad gallandis ga graith a gyiss, And last vp gamountis in the skyiss, That last came out of France.

"Lat se," quod he, "Now quha begynnis;"

With that the fowll Sevin Deidly Synnis

Begrowth to leip at anis.

And first of all in dance wes Pryd,

With bair wyld bak and bonet on syd,

Lyk to mak vaistie wanis;

And round abowt him, as a guheill,

Hang all in rumpillis to the heill

His kethat for the nanis:

Mony prowd trumpour and his trippit

Throw skaldand fyre, ay as thay skippit

That hrynd with hiddouss granis.

Heilie harlottis on hawtane wyiss

Come in with mony sindrie gyiss,

Bot yit luche nevir Mahoun;

Quhil1 preistis come in with bair schevin nekkis,

Than all the feyndis lewche, and maid gekkis,

Blak Belly and Bawsy Brown.

Than yre come in with sturt and stryfe;

His hand wes ay vpon his knyfr,

He brandiest lyk a beir:

Bostaris, braggaris, and barganeris,

Eftir him passit in to pairis,

A11 bidin in fier of weir:

In lakkis, and stryppis and bonettis of steill,

Thair leggis wer chenyeit to the heill,

Ffrawart wes thair affeir:

Sum vpoun vdir with brandis beft,

Sum jaggit vthiris to the heft,

With knyvis that scherp cowd scheir. 
Nixt in the dance followit Invy, Fild full of feid and fellony, Hid malyce and dispyte;

Ffor pryvie hatrent that tratour trymlit. Him followit mony freik dissymlit, With-fenyeit wirdis quhyte;

And flattereris in to menis facis; And bakbyttaris of sindry racis, To ley that had delyte;

And rownaris of fals lesingis;

Allace! that courtis of noble kingis

of thame can nevir be quyte.

Nixt him in dans come Cuvatyce, Rute of all evill and grung of vyce, That nevir cowd be content; Catyvis, renchis and okkeraris, Hud-pykis, hurdaris and gadderaris, A11 with that warlo went:

Out of thair throttis thay schot a fudder, As. fyreflawcht maist fervent:

Ay as thay tomit thame of schot, Ffeyndis fild thamt new vp to the thrott With gold of allkin prent.

Syne Sweirnes, at the secound bidding, Come lyk a sow out of a midding, Full slepy wes his grunyie:

Mony sweir bumbard belly hyddroun, Mony slute daw and slepy duddroun, Him serwit ay with sounyie;

He drew thame furth in till a chenyie, And Belliall, with a brydill renyie, Evir lascht thame on the lunyie: In danse thay war so slaw of feit, Thay falf thame in the fyre a heit, And maid thame quicker of counyie.

Than Lichery, that lathly corss, Berand lyk a bagit horss, And Ydilness did him leid; Thair wes with him any vgly sort, And mony stynkand fowll tramort, That had in syn bene deid. 
Quhen thay wer entrit in the dance, Thay we full strenge of countenance, Lyk turkass birnand reid;

All led thay vthir by the tersis, Auppoiss thay fychet with thair ersis, It mycht be na remeid.

Than the fowll monstir Glutteny, off wame vnsaisiable and gredy, To dance he did him dress:

Him followit mony fowll drunckart, With can and collep, cop and quart, In surffet and excess;

Full mony a waistless wallydrag, With wamiss vnweildable, did furth wag, In creisch that did incress;

Drynk! ay thay crtit, with mony a gaip, The feyndid gaif thame hait leid to laip, Thair lovery was na less.

Na menstrallis playit to thame but dowt, Ffor gemen thair wer haldin owt, Be day, and eik by nycht;

Except a menstrall that slew a man, Swa till his heretage he wan, And entirt be breif of richt.

Than cryd Mahoun for a Heleand padyand; Syne ran a feynd to feche Makfadyane, Ffar Northwart in a nuke;

$\mathrm{Be}$ he the correnoch had done schout, Erschemen so gadderit him abowt, In Hell grit rowme thay tuke.

Thae tarmegantis, with tag and tatter, Ffull lowd in Ersche begwoth to clatter, And rowp lyk revin and ruke:

The Devill sa devit wes with thair yell, That in the depest pot of hell

He smorit thame with smvke. 
"Dunbar's Complaint" (\$57)

Complane I wald, wist I quhome till,

or wnto qyhome direct my bill;

Quhidder to God, that all thing steiris,

All thing seis, and all thing heiris,

And all thing wrocht in dayis seweyne;

Or till his Moder, Quein of Heweyne;

Or wnto warldie prince heir downe,

That dois for justice weir a crowne;

off wrangis, and of gryt iniuris

That nobillis in thar dayis indures,

And men of wertew, and cuning,

of wit, and visdome ingyding,

That nocht can in this cowrt conquyss

For lawte, liuff, nor lang servyss.

Bot fow 11, jow-jowrdane-hedit jevellis,

Cowkin-kenseis, and culroun kewellis;

Stuffettis, strekouris, and stafische strummellis;

Wyld haschbaldis, haggarbaldis, and hummellis;

Druncartis, dysouris, dyvowris, drewellis,

Misgydit memberis of the dewellis;

Mismad mandragis of mastyf strynd,

Crawdones, couhirttis, and theiffis of kynd;

Blait-mowit blaydyeanes, with bledder cheikis, Clug-facet cluccanes, with cloutit breikis, Chuff-midding churlis, cuming off cart-fillaris,

Gryt glaschew-hedit gorge millaris,

Ewill horrible monsteris, falss and fowl1;

Sum causless clekis till him ane cowll,

Ane gryt convent fra syne to tyss;

And he him-selff exanpill of vyss:

Enterand for geir, and no devotioun,

The dewell is glaid of his promotioun;

Sum ramyis ane dastart destroy;

And sum that gaittis ane personage,

Thinkis it a present for a page;

And on no watis contant is he,

My lord qyhill that he callit be.

Bot quhow is he content, or nocht,

Deme ye abowt in to your thocht!

The lerit sone of er 11 or 1ord,

Wpone this ruffie to remord,

That with ald castingis hes him cled,

His erandis for to ryne and red?

And he is maister natiwe borne,

And all his eldaris him beforne;

And mekle mair cuning be sic thre,

Hes to posseld ane dignite,

Saying his odius ignorance

Panting ane prelottis countenance,

Sa far abowe him sett at tabell 
That was for tu muk the stabe11:

Ane pyk-thank in a prelottis claiss, With his wawill feitt, and virrok taiss, With hoppir hippis, and henches narrow, And bausy handis to beir ane barrow; With lut schulderis, and luttaird bak, Quhilk natur maid to beir a pak;

With gredy mynd, and glaschand game, Mill-hedit lyk ane mortar-stane, Fenyeing the feiris of ane lord, And he ane strumbell, I stand ford;

And evir moir as he dois ryss, And nobillis of bluid he dois dispyss, And helpis for to hald thame downe, That they ryss nevir to his renowne, Thairfoir, O Prince maist honorable!

Be in this mater merciabill, And to thy schervandis have an $\mathrm{E}$, That lang hes lippinit inot the;

Gif I be ane of thay my sell, Throw all regiones hes bein hard tell, of quhilk my wrytting vitnes beris;

And yet thy danger ay me deris: Bot eftir danger cumis grace, As hes bein herd in mony place. 


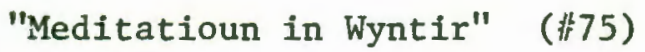

In to thir dirk and drublie dayis, Quhone sabill all the hewin arrayis,

With mystie vapouris, cluddis and skyis,

Nature ali curage me denyis

off sangis, ballattis, and of playis.

Quhen that the nycht dois lenthin houris,

With wind, with haill, and havy schouris,

My dule spreit dois lurk for schoir;

My hairt for languor dois forloir,

For lalk of symmer with his flouris.

I walk, I turne, sleip may I nocht,

I vexit am with havy thocht;

This warld all ouir I cast about, And ay the mair $I$ am in dout,

The mair that I remeid have socht.

I am assayit on everie syde,

Dispair sayis ay, "In tyme prowyde, And get sum thing quhairno to leif;

Or with grit trouble and mischeif,

Thow sall in to this court abyde."

Than Patience sayis, "Be nocht agast:

Hald Hoip and Treuthe within the fast;

And lat Fortoun wirk furthe hir rage, Quhen that no rasoun may assuage, Quhill that hir glas be run and past."

And Prudence in my eir sayis ay,

"Quhy wald thow hald that will away? Or. craif that thow may have no space, Thow tending to ane uther place,

A journay going everie day?

And than sayis Age, "My freind, cum neir, And be nocht strange, I the requeir:

Cum, brodir, by the hand me tak,

Remember thow hes compt to mak

off all thi tyme thow spendit heir."

Syne Deid castis up his yettis wyd, Saying, "Thir oppin sall ye abyd; Albeid that thow were never sa stout, Vndir this lyntall sall thow lowt:

Thair is nane vther way besyd." 
For feir of this all day $I$ drowp;

No gold in kist, nor wyne in cowp

No ladeis bewtie, nor luiffis blys

May lat me to remember this:

How glaid that ever I dyne or sowp.

Yit, quhone the nycht begynnis to schort, It dois my spreit sum part confort, off thocht oppressit with the schouris. Cum, lustie symmer! with thy flouris, That I may leif in sum disport.

Quod Dumbar. 